\author{
Universidade de São Paulo \\ Escola de Enfermagem de Ribeirão Preto
}

O tratamento supervisionado no domicílio para o controle da tuberculose no município de Ribeirão Preto, SP-Brasil:

avaliação do desempenho

Roxana Isabel Cardozo Gonzales 
Roxana Isabel Cardozo Gonzales

\title{
O tratamento supervisionado no domicílio para o controle da tuberculose no município de Ribeirão Preto, SP-Brasil: avaliação do desempenho
}

\begin{abstract}
Tese apresentada à Escola de Enfermagem de Ribeirão Preto da Universidade de São Paulo, para obtenção do Título de Doutor em Enfermagem em Saúde Pública, junto ao Departamento de Enfermagem Materno-Infantil e Saúde Pública, inserida na Linha de Pesquisa: Práticas, saberes e Políticas de Saúde.
\end{abstract}

Orientadora: Profa. Dra. Tereza C. Scatena Villa 
Autorizo a reprodução e divulgação total ou parcial deste trabalho, por qualquer meio convencional ou eletrônico, para fins de estudo e pesquisa desde que citada a fonte.

Ficha Catalográfica elaborada pela Biblioteca Central Campus USP - Ribeirão Preto

Cardozo-Gonzales, Roxana Isabel

O tratamento supervisionado no domicílio para o controle da tuberculose no município de Ribeirão Preto, SP - Brasil: avaliação do desempenho

100p.: il.; 30cm.

Tese de Doutorado, apresentado à Escola de Enfermagem de Ribeirão Preto/USP - Departamento de Enfermagem Materno Infantil e Saúde Pública.

Orientador: Villa, Tereza Cristina Scatena

1. Avaliação de desempenho. 2. Directly Observed Therapy. 3. Tuberculose 


\section{FOLHA DE APROVAÇÃO}

Roxana Isabel Cardozo Gonzales

Título: O tratamento supervisionado no domicílio para o controle da tuberculose no município de Ribeirão Preto, SP-Brasil: avaliação do desempenho

Tese apresentada à Escola de Enfermagem de Ribeirão Preto da Universidade de São Paulo, para obtenção do Título de Doutor em Enfermagem em Saúde Pública.

Aprovado em:

\section{Banca Examinadora}

Prof. Dr. Tereza Cristina Scatena Villa

Instituição:EERP - USP.

Assinatura:

Prof. Dr. Antonio Ruffino Netto

Instituição: FMRP - USP

Assinatura:

Prof. Dr. Ione Carvalho Pinto

Instituição: EERP- USP

Assinatura:

Prof. Dr.Lucila Amaral Carneiro Vianna

Instituição: UNIFESP

Assinatura:

Prof. Dr. Jordana Nogueira Muniz

Instituição: SMS - RP

Assinatura: 


\section{DEDICO ESTE TRABALHO}

A minha mãe, por ter possibilitado minha existência, pela sua história de vida, meu maior estímulo na busca do crescimento pessoal e profissional, pelo exemplo de entrega total na realização de nossos sonhos. Sinto saudades, porém, sinto-a perto, principalmente hoje, pois um de nossos grandes sonhos está sendo uma realidade.

Te amo, para sempre 


\section{Agradecimento Especial}

À Profa. Dra. Tereza Scatena Villa, "Tite”, pela acolhida, e constante presença em minha carreira científica, por me direcionar nas tantas trilhas dessa longa caminhada, por ter sido fundamental nesse processo. Agradeço também pela sua presença nos momentos difíceis que vivenciei.

Parabéns pelo dom de dividir conhecimentos, pela capacidade de integrar pessoas e nos encorajar a explorar nossas potencialidades por meio de constantes desafios. 


\section{Agradecimento Especial}

Ao Prof. Dr. Antonio Ruffino-Netto, "grande ser humano" com quem tive o privilégio de me renovar pessoal e profissionalmente. Por me mostrar que é possível avançar na nossa carreira profissional sem perder a sensibilidade, a emoção e o respeito pelo próximo. Obrigada pela ajuda e por contemplar meu pequeno mundo intelectual. Parabéns pelo dom da humildade, apesar da sua grandeza. 


\section{AGRADECIMENTOS}

A Deus, por me permitir alcançar este momento acompanhada de meu pequeno André.

Ao meu pai Álvaro e meus irmãos Manuel e Carlos pela alegria de sentir que somos e continuaremos sendo uma família. É bom ter vocês a meu lado.

Ao Enrique pelo amor, companhia, compreensão e por sempre compartilhar meus sonhos. Obrigada pela paciência.

À Márcia, minha grande amiga, sempre solícita e gentil - você foi fundamental em vários momentos importantes da minha vida. Obrigada pela segurança de poder contar com você em qualquer momento.

À Kattia, minha amiga de longas caminhadas, obrigada pela companhia em momentos importantes e difíceis, pequenos gestos que foram fundamentais nesta jornada.

À Sandri, pela amizade e sensibilidade. Muito obrigada por compartilhar as minhas emoções.

À Marita, pela amizade, por acompanhar e compartilhar momentos da minha vida. Lembrarei com carinho de sua participação na impressão deste trabalho.

À Mônica, pelo seu jeito especial, sempre solícita e gentil.

A Ani e Ida, por fazer de cada encontro um momento familiar e de alegria. 
A Aline, Cinthia e Paulinha por me mostrarem que a amizade e a solidariedade não têm fronteiras. Muito obrigada por estarem sempre presentes fazendo parte de muitos momentos especiais na minha vida. Se algum dia o destino nos separar, André e eu sempre nos lembraremos de vocês com muitas saudades.

Ao Dr. Luís Carlos Raya, Secretário Municipal da Saúde de Ribeirão Preto in memoriam, por ter permitido a realização desse estudo na rede básica de saúde da Secretaria Municipal da Saúde.

À Jordana pela solicitude e presteza sempre presentes no atendimento.

Ao grupo de pesquisa GEOTB da REDE-TB e da Escola de Enfermagem de Ribeirão Preto, pelo convívio estimulante e colaboração permanente.

À Cooperação de Apoio à Pesquisa de Ensino Superior (CAPES), pela concessão de bolsa estudo e apoio financeiro a este trabalho.

A todos os profissionais do Programa de Controle da Tuberculose que participaram do estudo. Obrigada pela ajuda. Vocês foram elementos necessários para que eu pudesse viabilizar este estudo.

À funcionária Adriana da Pós-Graduação do Departamento de Enfermagem Materno Infantil e Saúde Pública da Escola de Enfermagem de Ribeirão Preto, pela atenção e apoio dispensados em todos os momentos.

Às funcionárias da sala de leitura Glete de Alcântara, Deolinda e Lourdes pelo auxílio e atenção. 
Aos membros da banca examinadora, Dra. Ione, Dr Antônio Ruffino Neto, Dra. Lucila Amaral Carneiro Vianna e Dra. Jordana Nogueira Muniz pela compreensão e ajuda na conclusão deste estudo.

Enfim, agradeço a todos que participaram e contribuíram de alguma maneira para a realização deste trabalho. 


\section{SUMÁRIO}

LISTA DE TABELAS

LISTA DE GRÁFICOS

LISTA DE ABREVIATURAS E SIGLAS

APRESENTAÇÃO 01

1. CONSTRUÇÃO DA TEMÁTICA EM ESTUDO 05

1.1A tuberculose - magnitude do problema 06

1.2 Directly Observed Therapy Short-Curse - DOTS 07

1.3 Tuberculose no Brasil - Implantação do DOTS 16

2. DELIMITAÇÃO DO OBJETO DE ESTUDO 26

3. PRESSUPOSTO 30

4. OBJETIVOS 32

5. QUADRO TEÓRICO - Avaliação de Serviços e Programas de Saúde.... 34

6. METODOLOGÍA 41

a. Descrição das unidades de saúde que desenvolvem o DOTS/TS 43

b. Construção de indicadores $\quad 45$

c. Coleta de dados $\quad 47$

d. Características da população em estudo 48

e. Análise dos resultados 49

7. RESULTADOS E DISCUSSÃO 53

8. CONCLUSÕES 79

9. CONSIDERAÇÕES FINAIS

REFERÊNCIAS BIBLIOGRÁFICAS

ANEXOS (I, II, III, IV) 


\section{LISTA DE TABELAS}

Tabela 1.1 - Cobertura da Implantação da Estratégia DOTS nos países da América (2000) 09

Tabela 1.2 - Implantação e extensão do DOTS nos países da América (2000) 09

Tabela 6.1 - Unidades básicas e população estimada para as unidades de saúde no ano de 51 2004, segundo área de abrangência

Tabela 6.2 - Disponibilidade dos recursos para realizar o DOTS/TS no domicílio

Tabela 7.1 - Cobertura do DOTS/TS nos PCT das unidades de saúde do município 54 Ribeirão Preto, julho, 2003

Tabela 7.2 - Equipe de saúde dos PCT nas unidades de saúde do município de Ribeirão 57 Preto, julho, 2003

Tabela 7.3 - Número médio de visitas domiciliares por unidades de saúde segundo hora 67 gasta dos recursos do DOTS/TS no domicílio

Tabela 7.4 - Porcentagem de visitas domiciliares com observação de ingestão da 70 medicação por PCT no município de Ribeirão Preto, 2003

Tabela 7.5 - Tempo médio disponível e gasto por visita domiciliar no DOTS/TS por PCT 73 no município de Ribeirão Preto, 2003 


\section{LISTA DE GRÁFICOS}

Gráfico 1.1 - Cobertura em porcentagem dos casos supervisionados em Ribeirão

Preto, nos anos de 1998 a 2004

Gráfico 1.2 - Porcentagem de casos curados de tuberculose em residentes no município 24 de Ribeirão, Preto de 1993 a 2003

Gráfico 1.3 - Porcentagem de abandono de tratamento da tuberculose em residentes no 25 município de Ribeirão Preto, nos anos de 1993 a 2003

Gráfico 2.1 - Cobertura em porcentagem do DOTS/TS em unidades de saúde, nos anos 27 de 1998 a 2004

Gráfico 7.1 - Tempo de aproveitamento dos recursos do DOTS/TS no por PCT, 2003

Gráfico 7.2 - Distribuição dos tempos disponíveis dos recursos do DOTS/TS nos PCT 62 segundo média e intervalo de confiança, 2003

Gráfico 7.3 - Distribuição dos tempos gastos dos recursos do DOTS/TS no domicílio por PCT segundo média e intervalo de confiança, 2003

Gráfico 7.4 - Distribuição de números de visitas domiciliares realizadas no DOTS/TS por PCT segundo média e intervalo de confiança, 2003

Gráfico 7.5 - Tempo médio disponível e tempo médio gasto por visita domiciliar no DOTS/TS 


\title{
LISTA DE ABREVIATURAS E SIGLAS
}

\author{
AIDS Acquired Immune Deficiency Syndrome \\ GEOTB Grupo de Estudos Operacionais em Tuberculose \\ DIRXVIII Direção Regional de Saúde \\ DOTS Directly Observed Therapy Short - Course \\ DOTS/TS Directly Observed Therapy Short - Course/Tratamento Supervisionado \\ DOTS PLUS Estratégia para o Tratamento da Tuberculose Multirresistente \\ DST Doença Sexualmente Transmissíveis \\ HIV Human Immunodeficiency Virus \\ IBGE Instituto Brasileiro de Geografia e Estatística \\ OMS Organização Mundial da Saúde \\ OPAS Organização Pan-Americana de Saúde \\ PCT Programa de Controle da Tuberculose \\ SMS Secretaria Municipal de Saúde \\ TA Tratamento Auto-Administrado \\ TB Tuberculose
}




\section{RESUMO}

CARDOZO-GONZALES, R.I. O Tratamento Supervisionado no Domicílio para o Controle da Tuberculose no Município de Ribeirão Preto, SP. - Brasil: avaliação do desempenho. Ribeirão Preto, 2005. 100 f. (Doutorado em Saúde Pública) - Escola de Enfermagem de Ribeirão Preto, Universidade de São Paulo.

Trata-se de um estudo exploratório cujo objetivo foi avaliar o "desempenho" dos serviços de saúde que executam o DOTS/TS Domiciliar no Programa de Controle da Tuberculose (PCT) em Unidades de Saúde do Município de Ribeirão Preto. Utilizou-se como referencial metodológico os enfoques básicos para avaliação da qualidade da atenção médica EstruturaProcesso-Resultado proposto por Donabedian (1980) e modificado por Tanaka e Melo (2001) e Starfield (2002). Elaborou-se os seguintes indicadores: Cobertura, Aproveitamento dos recursos, Agilidade do desempenho, Monitoração da administração da medicação e Tempo gasto por visita domiciliar. Os dados foram coletados em 4 PCT por meio da Técnica de Observação Sistemática das visitas domiciliares, realizadas pelo profissional de saúde responsável pela supervisão do tratamento do paciente durante o mês de julho de 2003. Foram acompanhados todos os pacientes que no período em estudo receberam DOTS/TS no domicílio e aqueles que foram incluídos na supervisão durante a coleta de dados. A avaliação do desempenho foi realizada na relação de indicadores e complementada em função da análise por indicador a partir da média e do intervalo de confiança. Os indicadores estudados mostraram que o planejamento de recursos, a organização do trabalho pela equipe de saúde, a definição de funções e a sistematização das ações no processo de tratamento do doente de tuberculose podem influenciar no melhor desempenho do serviço de saúde em termos de cobertura, aproveitamento dos recursos, agilidade, monitoração da administração da medicação e tempo gasto por visita domiciliar. Assim, perante as restrições de recursos humanos e materiais no setor saúde, existe a necessidade de reconsiderar outras formas de supervisão e/ou integração das atividades de tratamento e controle da doença a outras estratégias de intervenção que resultem no uso racional dos recursos, melhor cuidado de saúde e sucesso do tratamento.

Palavras-chave: Avaliação de desempenho, Tratamento diretamente observado, Tuberculose 


\section{RESUMEN}

CARDOZO-GONZALES, R.I. El Tratamiento Supervisado en el Domicilio para el Control de la Tuberculosis en el Municipio de Ribeirão Preto, SP. - Brasil: evaluación del desempeño. Ribeirão Preto, 2005. 100 f. (Doctorado en Salud Pública) - Escuela de Enfermería de Ribeirão Preto, Universidad de São Paulo.

Se trata de un estudio exploratório cuyo objetivo fue analisar el "desempeño" de los servicios de salud que realizan el DOTS/TS Domiciliario en el Programa de Control de la Tuberculosis (PCT) en Unidades de Salud del Municipio de Ribeirão Preto. Se utilizó como referencial metodológico los enfoques básicos para la evaluación de la calidad de la atención médica Estructura-Proceso-Resultado propuesto por Donabedian (1980) y modificado por Tanaka y Melo (2001) y Starfield (2002). Se elaboró los siguientes indicadores: Cobertura, Aprovechamiento de los recursos, Agilidad del desempeño, Monitoración de la administración de la medicación y Tiempo gasto por visita domiciliaria. Los datos fueron recolectados en 4 PCT por medio de la Técnica de Observación Sistemática de las visitas domiciliarias realizadas por el profesional de salud responsable por la supervisión del tratamiento del paciente durante el mes de julio de 2003. Fueron acompañados todos los pacientes que en el período en estudio estuvieron recibiendo DOTS/TS en el domicilio, así como, aquellos que fueron incluídos en la supervisión durante la recolecta de datos. La evaluación del desempeño fue realizada en la relación de indicadores y complementada en función del análisis por indicador, apartir de la média y el intérvalo de confianza. Los indicadores estudiados mostraron que el planeamiento de recursos, la organización del trabajo por el equipo de salud, la definición de funciones y la sistematización de las acciones en el proceso del tratamiento del el enfermo de tuberculosis pueden influenciar en el mejor desempeño del servicio de salud en relación a cobertura, aprovechamiento de los recursos, agilidad, monitoración de la administración de medicamentos e tiempo gasto por visita domiciliar. Considerando las restricciones de recursos humanos y materiales en el sector salud, existe la necesidad de reconsiderar otras formas de supervisión y/o integración de actividades de tratamiento y control de la enfermedad a otras estrategias de intervención que resulten en el uso racional de los recursos, mejor cuidado de la salud y suceso del tratamiento.

Palabras-clave: Evaluación de desempeño, Tratamiento directamente observado, Tuberculosis. 


\section{ABSTRACT}

CARDOZO-GONZALES, R.I. Domiciliary Supervised Treatment for Tuberculosis Control in Ribeirão Preto, SP. - Brazil: performance evaluation. Ribeirão Preto, 2005. 100f. Doctoral Thesis - University of São Paulo at Ribeirão Preto College of Nursing.

This exploratory study aimed to evaluate the "performance" of health services that execute Domiciliary DOTS/TS in the Tuberculosis Control Program (TCP) at Health Units in Ribeirão Preto. The methodological reference framework was based on the basic focuses for medical care quality evaluation Structure-Process-Outcome proposed by Donabedian (1988) and modified by Tanaka and Melo (2001) and Starfield (2002). The following indicators were elaborated: Coverage, Use of recourses, Performance agility, Medication administration monitoring and Time spent per home visit. Data were collected in 4 TCP by means of the Systematic Observation Technique of home visits, realized by the health professional who was responsible for supervising the patient's treatment in July 2003. All patients were accompanied who were receiving domiciliary DOTS/TS during the study period, as well as those included in the supervision during data collection. The performance evaluation was accomplished in the indicator list and complemented in function of the analysis per indicator, based on mean values and confidence intervals. The studied indicators demonstrated that the planning of resources, the health team's organization of its work, the definition of function and the systemization of actions in tuberculosis patients' treatment can influence in the sense of achieving a better performance by the health service in terms of coverage, use of resources, agility, medication administration monitoring and time spent per home visit. Thus, in view of health sector restrictions in terms of human and material resources, there is a need to reconsider other forms of supervising and/or integrating treatment and control activities with other intervention strategies that can result in the rational use of resources, a better healthcare and a successful treatment.

Keywords: Health program assessment, DOTS strategy, Tuberculosis Control Program. 


\section{APRESENTAÇÃO}

O interesse em estudar esta temática surgiu a partir dos resultados obtidos em alguns trabalhos desenvolvidos por Muniz (1999) e Muniz e Villa (1999), que apontaram a necessidade de um olhar mais detalhado para a possibilidade de novas propostas de intervenção na assistência ao doente/família com tuberculose (TB), bem como avaliar os resultados do Programa de Controle de Tuberculose (PCT) e das estratégias de intervenção no controle da doença no município de Ribeirão Preto - SP.

A escolha do objeto de estudo surgiu das discussões no Grupo de Estudos Operacionais em Tuberculose (GEOTB) ${ }^{1}$ da Rede Brasileira de Pesquisa em TB - REDE-TB, que vem estudando a problemática da TB a partir das seguintes dimensões: A TB e o sistema de atenção à saúde (RUFFINO-NETTO, 1999, 2001, 2002); Adesão ao tratamento da tuberculose na visão do doente e família (VENDRAMINI, 2001, 2002; MONROE et al., 2001); Estratégias de implantação do tratamento supervisionado (TS) e a perspectiva de trabalho no território (MUNIZ, 1999; MUNIZ; VILLA, 1999; VILLA et al., 2002; HINO, 2004; MONROE et al., 2005); Indicadores epidemiológicos da doença (GAZETTA, 1999; WATANABE; RUFFINO-NETTO, 1995; MUNIZ; VILLA, 2002; MUNIZ; VILLA; FERREIRA, 2002; SANTOS et al., 2002; SASSAKI, 2002, 2003) e O programa de agentes comunitários de saúde na identificação de sintomáticos respiratórios no controle da tuberculose (MUNIZ, 2004).

O GEOTB é constituído por uma equipe multidisciplinar, onde predomina uma equipe de pesquisadores do Departamento de Enfermagem Materno-Infantil e Saúde Pública da Escola de Enfermagem de Ribeirão Preto da Universidade de São Paulo (EERP-USP), vinculado à linha de pesquisa Práticas, Saberes e Políticas de Saúde.

\footnotetext{
${ }^{1}$ O GEOTB é cadastrado no CNPq desde 2002 - Diretório dos Grupos de Pesquisa no Brasil. A equipe responsável pelo projeto é composta por pesquisadores e profissionais de outras instituições de saúde, formadoras e prestadoras de serviços de saúde, sob a coordenação do Prof. Dr. Antonio Ruffino Netto e da Profa . $\mathrm{Dr}^{\mathrm{a}}$ Tereza Cristina Scatena Villa.
} 
O presente estudo se ocupa dos processos de assistência na esfera dos serviços, no PCT com recorte para uma tecnologia de gestão do cuidado, que é o Directly Observed Therapy Short-Course - (DOTS) ou Tratamento Supervisionado - TS (DOTS/TS) no controle da TB.

O desempenho da assistência prestada pelo DOTS/TS enquanto uma tecnologia de gestão do cuidado planejado pela equipe do PCT e executado por um profissional de saúde inclui as seguintes atividades: avaliar o perfil sócio cultural e econômico do doente, verificar como este interage com a assistência à saúde prestado pelo PCT, sua aceitação e participação no plano terapêutico e adesão ao tratamento.

Nesse processo, a interface entre o profissional de saúde e o doente de TB assume um papel importante, uma vez que o resultado dessa mediação terá influência para uma maior ou menor co-responsabilidade do doente no tratamento.

Utilizaram-se como referencial metodológico, os enfoques básicos para avaliação da qualidade da atenção médica Estrutura-Processo-Resultado proposto por Donabedian (1980) e modificado por Tanaka e Melo (2001) e Starfield (2002).

O componente processo refere-se ao núcleo de atividades essenciais que caracterizam o DOTS do PCT (TANAKA; MELO, 2001). também é denominado por Starfield (2002) como desempenho, envolvendo tanto ações por parte dos profissionais de saúde no sistema quanto ações recebidas das populações e dos clientes. Portanto, os termos processo e desempenho serão utilizados como sinônimos para se referir ao mesmo componente da avaliação.

O objetivo do estudo foi avaliar o desempenho dos serviços de saúde que executam o DOTS/TS no domicílio em Unidades de Saúde do Município de Ribeirão Preto - SP, uma vez que, no município, tem-se privilegiado este espaço como local de atuação para a prática do DOTS/TS. 
A fim de alcançar o objetivo proposto, foram construídos alguns indicadores: cobertura do DOTS/TS, aproveitamento dos recursos, agilidade do desempenho, monitoração da administração da medicação e tempo gasto por supervisão nos PCT.

A escolha destes indicadores teve como finalidade identificar não apenas as principais características que envolvem o processo de execução do DOTS/TS no domicílio, como também a forma de utilização dos recursos para a supervisão do tratamento do doente no domicilio, no intuito de reconhecer problemas e identificar soluções executáveis que possibilitem melhorar a efetividade das atividades do DOTS/TS e a otimização dos recursos.

A escolha dos indicadores foi produto de contínuas discussões com a orientadora da pesquisa e com o GEOTB, norteados pela relevância e aplicabilidade de cada um deles. Elaborou-se indicadores de processo (atividade principal do DOTS/TS) e da estrutura (recursos materiais e humanos).

Cabe mencionar que a execução do DOTS/TS no domicílio não é possível sem uma estrutura mínima que permita desenvolver as atividades inerentes ao tratamento do doente de TB. Os indicadores construídos incluem alguns elementos da estrutura correspondentes aos recursos materiais e humanos que possibilitam ao PCT prestar o DOTS/TS, tais como instalações, condução (viatura) e recursos humanos (motorista e profissional de saúde responsável pelo DOTS/TS no PCT).

Na descrição do estudo, apresentam-se o conteúdo na forma de capítulos. No primeiro capítulo aborda-se a construção da temática focalizando a amplitude do problema da tuberculose, fazendo referência às três dimensões incorporadas pelos esforços globais e atuais para o controle da doença (humanitária, saúde pública e econômica).

Em seguida, contextualiza-se o cenário da doença, mostrando-se a necessidade da aplicação do DOTS como uma estratégia capaz de mudar o perfil epidemiológico da TB, destacando os 5 elementos que o conformam. Além disso, contempla-se também a situação do 
DOTS nas Américas e ressalta-se os empreendimentos e as dificuldades enfrentadas pelos países que adotaram tal estratégia. Posteriormente, o desenvolvimento do DOTS no Brasil e, finalmente, no Município de Ribeirão Preto - SP.

O segundo capítulo contempla a delimitação do objeto de estudo, o recorte foi a situação da estratégia DOTS nos serviços de saúde que executam o DOTS/TS no Domicílio em Unidades de Saúde do Município de Ribeirão Preto.

O capítulo três apresenta os pressupostos. Logo a seguir vem o capítulo quatro que traz os objetivos do estudo, geral e específicos. O Quadro Teórico, fundamentado na Avaliação de Programas de Saúde se encontra no capítulo cinco.

No capítulo seis descreve-se a metodologia, a forma como o estudo foi desenvolvido, fazendo referência à população, construção de indicadores de avaliação do desempenho do DOTS/TS, campo de investigação e análise de dados. Posteriormente apresenta-se os resultados e discussão (capitulo sete), conclusões (capitulo oito), considerações finais (capitulo nove) e finalmente as referências bibliográficas e anexos. 


\section{CONSTRUÇÃO DA TEMÁTICA EM ESTUDO}

\subsection{A tuberculose - magnitude do problema}

A tuberculose (TB) é uma enfermidade antiga que persiste como problema sério de saúde pública, necessitando de uma urgente atenção. Segundo estimativas da Organização Mundial de Saúde (OMS), dois bilhões de pessoas correspondendo a um terço da população mundial está infectada pelo bacilo Mycobacterium tuberculosis, que causa a TB. Destes, 8 milhões desenvolverão a doença e 2 milhões morrerão a cada ano. (BRASIL, 2004). Entre as razões para tal cenário deve-se assinalar: desigualdade social e suas implicações; aglomerados humanos populacionais, advento da Acquired Immune Deficiency Syndrome (AIDS), movimentos migratórios e envelhecimento da população. Nas últimas décadas o controle da TB foi grandemente negligenciado pelas políticas públicas, pela sociedade e mesmo pela comunidade científica na falsa ilusão de que o problema estaria resolvido e/ou sob controle. Acrescenta-se a estes fatos o aumento progressivo de bacilos multirresistentes aos medicamentos disponíveis no mercado (WORKSHOP - REDE BRASILEIRA DE PESQUISA EM TUBERCULOSE, 2002).

Os esforços globais e atuais para o controle da doença justapõem três distintas dimensões: humanitária, saúde pública e econômica. Aliviar a doença, o sofrimento e a morte dos indivíduos por TB, assim como, a participação para discussão de outras formas de cuidados de saúde centradas no indivíduo, constituem-se nos maiores interesses humanitários. Na dimensão da saúde pública, o interesse é o diagnóstico e tratamento dos clientes para diminuir a transmissão da doença nas comunidades. Para isto, precisa do desenvolvimento de um Programa de Controle da Tuberculose (PCT) bem organizado, que dê resposta e se adapte à reforma do setor saúde. Na dimensão econômica, o controle da TB está relacionado à 
redução dos custos diretos e indiretos para os indivíduos e para a sociedade, alívio de pobreza e promoção do desenvolvimento (WHO, 2002a).

Calcula-se que a doença gera para as comunidades pobres um custo econômico anual equivalente a 12 milhões de dólares. Alguns estudos indicam que, em conseqüência da doença, perdem-se aproximadamente três a quatro meses de trabalho. Isto dá lugar a uma média de renda potencial perdida de 20 a 30\% das rendas domésticas anuais. Para as famílias daqueles que morrem pela doença, a perda adicional quantifica-se próxima de 15 anos de ingressos pela morte prematura do doente (OPAS, 2002).

\subsection{Directly Observed Therapy Short-Course - DOTS}

Para a melhora do problema da TB, um novo marco de trabalho tem sido desenvolvido (WHO, 1994) e a estratégia DOTS tem sido introduzida. Os 5 elementos da estratégia considerados como essenciais para o controle global da TB são: 1. Compromisso político nas atividades básicas de controle da TB; 2. Detecção de casos por baciloscopia em todo doente sintomático respiratório que espontaneamente procure o serviço de saúde; 3. Esquemas de tratamento padronizados de seis a oito meses para, pelo menos, todo caso bacilifero, com tratamento diretamente supervisionado durante, no mínimo, os dois meses iniciais; 4. Suprimento regular e ininterrupto dos medicamentos padronizados; 5 Um sistema de registro e notificação de casos que permitam o acompanhamento dinâmico dos resultados de tratamento de cada doente e do PCT como um todo (WHO, 1999).

Desde a introdução do DOTS, no início da década de 90, são consideráveis os progressos no controle global da TB. No ano de 2001, 155 países (de 210) adotaram o DOTS correspondendo a uma cobertura populacional de 61\% (WHO, 2003). No ano de 2002 somaram-se 25 novos países, sendo a cifra atual 180 países, correspondendo a uma cobertura de 69\% (WHO, 2004). 
Embora o progresso seja considerável, ainda não tem sido o suficiente. Estima-se que 1/3 da população no mundo está infectada pelo Micobacterium tuberculosis. A cada ano, estima-se que 8.4 milhões de casos novos e 1.9 milhões de pessoas morrem da doença (WHO, 2002b). A marginalização e a pobreza no mundo têm piorado: 95\% de todos os casos e 98\% das mortes por TB ocorrem nos países com baixos recursos. Os países que adotam o DOTS deparam-se com muitas necessidades para ampliar os serviços a toda a população (WHO, 2002a).

O relatório do Comitê de Epidemia em TB, convocado pela World Health Organization (WHO) em Londres no ano de 1998, informou os resultados alcançados por alguns países, contudo, mostrou o reduzido progresso na implementação do DOTS em países com elevado número de casos de TB (WHO, 1998). Identificaram-se as maiores dificuldades para a implementação do DOTS e o comitê recomendou uma ampla participação multisetorial para o controle da doença. No final de 1998, a sociedade, num esforço conjunto, começou a unir os diferentes setores: saúde, social e econômico, na batalha contra a TB denominado inicialmente como Stop TB, foi legitimado pela Organização Mundial de Saúde (OMS). No ano 2000, o alto nível da Conferência Ministerial de Saúde e Finanças dos 20 países com mais alto número de casos de TB endossaram a parceria Stop TB, recebendo o nome de "Amsterdam Declaration” (WHO, 2000). Assim, a meta global de controle da TB estabelecida em 1991 na 54 Assembléia da Saúde Mundial foi reafirmada ${ }^{4}$ (WHO, 2002a).

\subsubsection{Situação do DOTS nas Américas}

Em 1996, dez países da América realizavam o DOTS, depois foram incorporados mais três, igualmente nos anos de 1997, 1998 e quatro em 1999. No ano 2000, o Paraguai adota a estratégia (Tabela 1.1).

\footnotetext{
4: Curar $85 \%$ de cura dos casos detectados com baciloscopia positiva e detectar $70 \%$ de casos novos de tuberculose com baciloscopia positiva.
} 
Tabela 1.1 - Cobertura da Implantação da Estratégia DOTS nos países da América (2000)

\begin{tabular}{lllll}
\hline$>$ de $90 \%$ & $>50 \%$ e $<89 \%$ & $>10 \%$ e $<49 \%$ & $<$ de $10 \%$ & Não DOTS \\
\hline Chile & Bolívia & El Salvador & Argentina & Guiana \\
Cuba & Belice & Haiti & Brasil & Suriname \\
EUA & Guatemala & México & Costa Rica & Caribe Inglês \\
Nicarágua & & Colômbia & Equador & \\
Peru & & Honduras & Panamá & \\
Porto Rico & & & Paraguai & \\
Uruguai & & & & \\
Venezuela & & & & \\
\hline
\end{tabular}

Fonte: Reunião Regional de Avaliação de PCT - OPAS, 2000.

Atualmente nove países alcançaram a cobertura total, outros ainda se encontram em fase de implantação/expansão ou necessitam de reforço (Tabela 1.2).

Tabela 1.2 - Implantação e extensão do DOTS nos países da América (2000)

\begin{tabular}{|c|c|c|c|c|}
\hline Carga de TB & $\begin{array}{l}\text { DOTS } \\
\text { Cobertura Total }\end{array}$ & $\begin{array}{l}\text { DOTS } \\
\text { A reforçar }\end{array}$ & DOTS em expansão & $\begin{array}{l}\text { DOTS } \\
\text { implantar }\end{array}$ \\
\hline Alta incidência & Peru & Bolívia & $\begin{array}{l}\text { R. Dominicana } \\
\text { Equador } \\
\text { Haití } \\
\text { Honduras }\end{array}$ & Guiana \\
\hline Média incidência & $\begin{array}{l}\text { Chile } \\
\text { Nicarágua } \\
\text { Venezuela } \\
\text { Belice }\end{array}$ & Guatemala & $\begin{array}{l}\text { Argentina } \\
\text { Colômbia } \\
\text { Brasil } \\
\text { El Salvador } \\
\text { México } \\
\text { Panamá } \\
\text { Paraguai }\end{array}$ & \\
\hline Baixa incidência & $\begin{array}{l}\text { Cuba } \\
\text { Uruguai } \\
\text { EUA } \\
\text { Porto Rico }\end{array}$ & & Costa Rica & $\begin{array}{l}\text { Canadá } \\
\text { Caribe Inglês }\end{array}$ \\
\hline
\end{tabular}

Fonte: Reunião Regional de Avaliação de PCT - OPAS, 2000

Embora o progresso seja considerável, ainda a TB é um problema de grande magnitude. A implementação e extensão do DOTS apresentam dificuldades e limitações. 
Na Argentina, a tendência da incidência de casos, nos últimos 15 anos, é diminuir, porém, a organização do gerenciamento dos casos, detecção e tratamento, ainda apresentam limitações. A implantação do DOTS é lenta e gradativa, precisando apoiar-se em um processo prévio de descentralização do tratamento/capacitação/supervisão e aplicação de diferentes alternativas para implementação da estratégia, elevar as taxas de cura e diminuir o abandono (OPAS, 2000).

A Bolívia está executando a estratégia DOTS desde 1995, envolvendo vários municípios das diferentes regiões. Existe compromisso político para enfrentar o problema da TB, considerado de alta prioridade, porém, ainda apresenta uma baixa detecção de sintomáticos respiratórios, insuficiente cobertura de controle da qualidade na rede de laboratório, equipes gerenciais insuficientes, tanto no nível central como nas regiões, falta de supervisão do tratamento na segunda fase e as taxas de cura não alcançam os níveis requeridos (OPAS, 2000).

O Brasil é o país com maior carga de TB nas Américas. Nos últimos 3 anos a tendência da morbidade dos casos novos apresenta uma mínima diminuição comparada com a observada no biênio 1995-1996. Em 1997, foi elaborado um projeto para iniciar a aplicação da estratégia DOTS em quatro Estados do Centro-Oeste. A implantação iniciou-se em 1998. Existe compromisso político das autoridades do Ministério de Saúde, porém, a organização, a capacitação e a supervisão do programa precisam ser fortalecidos nos níveis estaduais e municipais. A rede de laboratório precisa ser organizada com controle de qualidade da baciloscopia. O sistema de informação e registro deve adequar-se às novas estratégias. Requer a publicação e distribuição das normas nacionais do programa (OPAS, 2000).

Na Colômbia, a rede de laboratórios que realiza baciloscopia é adequada e está submetida aos requisitos do controle de qualidade, porém, a quantidade de sintomáticos respiratórios e baciloscopias realizadas são relativamente baixas. Em 1998, começaram a 
implantar a estratégia DOTS. Ainda precisam incrementar as capacitações do pessoal de saúde assim como as supervisões com o objetivo de ampliar e consolidar o DOTS. Em geral, precisa-se de um maior compromisso político com o PCT e de superar as mudanças produzidas pela reforma do setor saúde (OPAS, 2000).

A Costa Rica organizou o PCT de modo a ser hierarquizado pelo Seguro Social do país, garantindo, assim a disponibilidade de medicamentos, diagnóstico bacteriológico e infraestrutura adequada. Foram organizadas, em 1998, áreas demonstrativas para aplicar o DOTS. O sistema de Vigilância Epidemiológica e de informação do PCT tem sido reforçado porém o programa ainda enfrenta problemas relacionados ao sistema de informação, que carece de sistematização e continuidade. Falta capacitação de pessoal e supervisão sistemática nos serviços de saúde. O controle de contatos é inexistente. Os resultados de tratamento são insatisfatórios (OPAS, 2000).

El Salvador é um dos países com mediana incidência de TB e em processo de expansão da estratégia DOTS. A rede de laboratório tem uma excelente cobertura, é eficiente e está submetida ao controle de qualidade. O PCT enfrenta ainda alguns problemas como a insuficiência de supervisão nas unidades periféricas. A taxa de cura do esquema de tratamento de curta duração está abaixo dos $80 \%$, no entanto, os abandonos e transferências são consideráveis (OPAS, 2000).

A TB no Equador representa um sério problema de saúde pública, com um programa de controle muito insuficiente nos últimos anos. Apesar de um importante sub-registro das notificações, a tendência da incidência de TB mostra um aumento. Observa-se uma melhoria no compromisso governamental em relação ao controle da doença, porém, o PCT tem sido altamente ineficiente nos últimos anos, sem conseguir que as ações de saúde melhorem os indicadores epidemiológicos. O suprimento dos medicamentos de TB para todos os clientes diagnosticados é irregular (OPAS, 2000). 
Nos últimos nove anos, Guatemala apresenta uma incidência de casos novos com baciloscopia positiva aumentada. O PCT tem normas técnicas adequadas, drogas e material de laboratório, recursos financeiros para treinamento e supervisão, porém, ainda enfrenta problemas como: dificuldade de acesso e baixa cobertura; frágil coordenação com outras instituições do setor; capacitações e supervisões deficitárias; a rede de laboratórios mostra debilidade organizacional e falta de controle da qualidade; o sistema de registro e notificação de TB sobrecarregados e com pouca análise em nível intermediário local; vigilância epidemiológica do programa é ainda débil (OPAS, 2000).

Em Honduras, a TB constitui um importante problema de saúde pública, agravado pela epidemia do Human Immunodeficiency Virus (HIV). O Ministério da Saúde decidiu unir os programas DST/AIDS e TB. O suprimento de medicamentos de TB teve dificuldades para garantir o tratamento dos clientes. O comportamento da incidência na última década mostra uma clara tendência ao aumento. Em 1998, realizou-se o relançamento da estratégia DOTS, logrando ampliar a cobertura. Uma considerável proporção dos casos de TB é diagnosticada pela atenção secundária e a rede de laboratórios não conta com o manual de bacteriologia (OPAS, 2000).

O Haiti apresenta uma grave situação da TB. Desde 1997 vem trabalhando a implantação da estratégia DOTS. A rede de laboratórios e o controle de qualidade não estão adequadamente organizados. A estratégia DOTS se organizou em 30 unidades, supervisionando, só a primeira fase de tratamento, obtendo-se um êxito de 75\% comparado com o 65\% das áreas não DOTS, porém, ainda é insuficiente a porcentagem de cura, assim como, a vigilância epidemiológica do HIV/TB e da resistência aos medicamentos de TB. Debilidades na estrutura intermediária e local do PCT, dificuldades econômicas e situação de pobreza estão muito presentes (OPAS, 2000). 
No México, o DOTS foi adotado a partir de 1995. Desde então, a implantação e extensão da estratégia é um êxito em virtude de vários fatores: o fortalecimento e a intensificação do programa, a consolidação da colaboração inter-institucional e a ampliação de projetos de colaboração com instituições nacionais e internacionais. Porém, continua sendo necessário incrementar a detecção dos casos por baciloscopia, controlar a qualidade da rede de laboratório, intensificar a capacitação/supervisão nas áreas que desenvolvem o DOTS, reforçar as equipes gerenciais do programa e melhorar as taxas de cura e abandono (OPAS, 2000).

No Panamá, a tendência da incidência de casos de TB nos últimos anos é ascendente apesar do sub-registro existente. A rede de laboratórios está em processo de reorganização para iniciar um plano de capacitação e supervisão. O PCT requer o fortalecimento de vários de seus principais componentes, devido à ineficiência da suas ações para produzir impacto nas metas de detecção e cura dos doentes de TB. A estratégia DOTS foi estabelecida com êxito em três áreas demonstrativas, existe compromisso político e perspectiva de ser implantado em outras áreas. O suprimento de medicamentos e insumos para o PCT é garantido. É importante destacar que a co-infecção HIV/TB está aumentando (OPAS, 2000).

No Paraguai, a TB é considerada um problema de alta prioridade. O comportamento da incidência é irregular, mostrando aumentos e diminuições devido às deficiências do registro e notificação. A rede de laboratório precisa ser organizada para garantir capacitações e supervisões. Foram organizadas áreas demonstrativas para o DOTS. Uma alta proporção de detecção e seguimento se realiza principalmente nos hospitais (forma centralizada), com pouco nível de referência e contra-referência dos clientes (OPAS, 2000).

O Chile cumpre em grau importante com todas as recomendações estabelecidas pela OMS para o controle da doença. O país está decidido a enfrentar a primeira etapa de eliminação da TB; apresenta uma excelente rede de diagnóstico com controle de qualidade, e 
uma cobertura de DOTS/TS em quase a totalidade dos casos. Um sistemático estudo da resistência às drogas mostra que o Chile não constitui um problema de saúde. Porém, apresenta diferenças importantes nas taxas de mortalidade e morbidade, segundo os serviços de saúde, devido à situação socioeconômica existente nos diferentes estratos populacionais. A eficiência do tratamento (82\%) ainda não alcançou as metas da OMS (OPAS, 2000).

O impacto obtido pelo PCT em Cuba é notável, apresentando 91\% de cura dos casos pulmonares baciliferos. É um dos países exemplo na aplicação do DOTS. É o país da América Latina que tem maiores possibilidades de passar para a fase eliminatória da TB (OPAS, 2000). No ano de 2004, apresentou cobertura DOTS de $100 \%$, detecção de caso com baciloscopia positiva de 91\% e 93\% de sucesso de tratamento (OPAS, 2004).

A Nicarágua começou a organizar a estratégia DOTS em 1984. Em 1988, todas as áreas de saúde do país haviam implementado a estratégia. Paralelamente, a rede de laboratórios foi reorganizada e submetida ao controle de qualidade. A organização da rede de laboratórios, o controle de qualidade do diagnóstico, a vigilância epidemiológica, a capacitação do pessoal e a supervisão das unidades se mantêm em níveis ótimos. Porém, a detecção de casos novos em vários locais ainda é insuficiente. O controle de qualidade dos laboratórios precisa de maior cobertura. A porcentagem de cura ainda é inferior a 85\% e o abandono é significativo (OPAS, 2000).

O Perú, na década de 90, realizou um excelente trabalho no PCT e com o apoio de outras instituições do setor saúde conseguiu reduzir a incidência de TB em 50\%. Isto demonstra a importância do compromisso político. A identificação de sintomáticos respiratórios, o incremento do número de baciloscopia de diagnósticos, a detecção de casos e os resultados de tratamento são excelentes, superando, desde 1995, as metas propostas pela OMS. Em 1997, começou a aplicar o DOTS/Plus administrando o tratamento padronizado aos doentes multirresistentes. Ainda, o PCT deverá aplicar estratégias diferenciadas para 
incrementar a busca e tratamento de casos nos bolsões de pobreza e buscar uma participação mais ativa dos médicos no programa (OPAS, 2000).

Na Venezuela, 87,6\% dos tratamentos são totalmente supervisionados. A porcentagem de êxito do tratamento é de 80,2\%. O abandono aumentou nos últimos anos, e isso é atribuído ao processo de reestruturação do setor saúde e às migrações internas. O Programa se fortaleceu nos últimos 5 anos. Existe garantia do suprimento de medicamentos a todos os clientes. A identificação dos sintomáticos respiratórios e a detecção dos casos novos de TB são inferiores ao estimado. Existem grandes grupos urbanos com alto risco de TB e também população indígena com dificuldade de acesso aos serviços de saúde (OPAS, 2000).

No Uruguai, o DOTS foi aplicado com êxito, conta com excelente vigilância sistemática de resistência aos medicamentos e da prevalência TB/HIV. O PCT ainda enfrenta problemas como: redução de verbas, detecção de alguns casos tardios, os resultados de tratamento ainda não superaram os $85 \%$ da meta estabelecida pelas organizações internacionais no combate à TB, existe elevado número de abandonos e falecidos. O PCT está trabalhando para passar à fase de eliminação da doença (OPAS, 2000).

É possível, portanto, observar muitas dificuldades que impedem a implementação e extensão sustentável das atividades do DOTS em muitos países com maior número de casos de TB. Muitas dessas dificuldades baseiam-se na fraqueza política, nas necessidades do sistema e na resposta da sociedade para o controle da doença.

Os serviços de saúde pública em geral precisam potencializar a capacidade para manter e ampliar o DOTS, comprometendo a qualidade na detecção e tratamento de casos de TB. O envolvimento da comunidade no cuidado da doença e modelos de cuidados de saúde centradas no indivíduo necessitam ser enfatizados e promover a melhora do acesso e utilização dos serviços de saúde. Colaboração e competência entre os serviços de saúde 
público, privado e setores voluntários são essenciais para assegurar a acessibilidade e a qualidade no diagnóstico e tratamento da TB (WHO, 2002).

De modo geral, empreendimentos e dificuldades na implementação do DOTS precisam adotar o novo marco de trabalho da estratégia para aumentar seu âmbito e para que este seja considerado como uma estratégia de amplo suporte - ajuda para todos os provedores, doentes e população em geral para manejar o problema da TB. O atual marco de trabalho do DOTS coloca igual ênfase na dimensão técnica, gerencial, social e política do DOTS. Isto reconhece o acesso para o cuidado da TB como um direito humano e o controle da doença como um bem social com grandes benefícios para a sociedade, assim, destaca que a contribuição do controle da TB promove o alívio da pobreza reduzindo o grande impacto sócio-econômico que a doença infligiu aos pobres (WHO, 2002).

A implantação e extensão do DOTS tornam-se cada vez mais necessária, diante do novo contexto no qual se desenvolve a doença como, por exemplo, o alto impacto de HIV na incidência da TB, especialmente, em Sub-Saharam África. O surgimento de formas de resistência às drogas de TB na antiga União Soviética e em várias outras partes do mundo precisam de efetiva implementação do DOTS para prevenir a ocorrência de novos casos de multirresistência.

A estratégia requer principalmente a integração do cuidado de saúde primária e adaptação contínua de reformas dentro do setor de saúde no mundo (WHO, 2002a).

\subsection{Tuberculose no Brasil - Implantação do DOTS}

\subsubsection{Compromisso político e financeiro na luta contra a tuberculose}

Atualmente, o Brasil ocupa o $15^{\circ}$ lugar na lista da OMS entre os países que precisam intensificar as ações de diagnóstico e tratamento da TB (WHO, 2004). O país tem cerca de 50 milhões de pessoas infectadas com o bacilo de Koch, mas que não desenvolveram o 
problema. A cada ano, 111 mil novos casos são registrados. A TB, que tem cura, ainda mata seis mil pessoas por ano no país (AGÊNCIA BRASIL, 2004). Fontes do Ministério da Saúde estimam uma prevalência no país de 58/ 100.000 casos/ habitantes. Segundo dados consolidados em 2001 pelo Sistema de Informação de Agravos de Notificação do Ministério da Saúde (SINAN/MS), foram notificados 81.432 casos novos, correspondendo a um coeficiente de incidência de 47,2/ 100.000 habitantes. Com relação ao tratamento, 72,2\% recebem alta por cura, com abandono de 11,7\% e 7\% de óbitos, distantes, portanto, das metas internacionais estabelecidas pela OMS e pactuadas pelo governo brasileiro, de curar 85\% dos casos estimados (BRASIL, 2004).

Os fatores limitantes para o controle efetivo da TB no geral estão relacionados a problemas com prevenção, diagnóstico, tratamento e a má qualidade dos serviços de saúde (WORKSHOP - REDE BRASILEIRA DE PESQUISA EM TUBERCULOSE, 2002).

A pedido do Ministério da Saúde do Brasil, o Programa Nacional de Controle da Tuberculose (PNCT) foi avaliado por peritos internacionais, os quais apontaram elevadas taxas de abandono e baixos percentuais de cura, exigindo prioridade na adoção das práticas existentes, bem como a implementação da capacidade de atuação do programa. A Coordenação Nacional de Pneumologia Sanitária (CNPS), responsável em nível nacional pelo controle da TB, no ano de 1994, apontou diretrizes para a elaboração do Plano de Ação Emergencial para os Municípios Prioritários, que apenas foi implementado em 1996. Este Plano tinha como principal meta o controle da TB, nos municípios onde a doença atingisse sua maior força no Território Nacional, e nos quais o emprego de recursos pudesse alcançar melhores resultados, proporcionando considerável impacto na redução da doença (BRASIL, 1997).

Deste modo, foram selecionados no Brasil, 230 municípios prioritários, mediante a análise de alguns indicadores. Entre os critérios para a inclusão, estabeleceu-se que o 
município deveria ter população acima de 50.000 habitantes, coeficiente de incidência acima da média brasileira (58,4/100.000 hab., em 1995), óbitos por TB acima de 5\% dos casos novos no ano, cura abaixo de $85 \%$, abandono acima de $10 \%$ e elevada incidência de casos de AIDS (BRASIL, 1997).

Estes municípios, a partir de 1997, receberam repasses financeiros por meio de um convênio com a Fundação Nacional de Saúde, o qual estipulava as obrigações/ restrições na aplicação dos recursos (BRASIL, 1997).

Por ocasião da proposição deste Plano, seus objetivos seriam alcançar até dezembro de 1998:

1. Integrar $100 \%$ dos municípios selecionados com ações de diagnóstico e tratamento da TB em pelo menos uma unidade de saúde;

2. Implementar diagnósticos bacteriológicos da TB, melhorando a rede de laboratórios e capacitação de recursos humanos;

3. Aumentar a cobertura do PCT, integrando $80 \%$ dos Centros de Saúde existentes na rede pública às ações de controle da TB;

4. Descobrir pelo menos $90 \%$ dos casos de TB existentes no país, implementando a busca de casos e identificando sintomáticos respiratórios na demanda aos serviços de saúde;

5. Aumentar a efetividade do tratamento submetendo $100 \%$ dos casos novos diagnosticados ao tratamento padronizado, curando pelo menos 85\%, implementando DOTS/TS para clientes com maior risco de abandono;

6. Desenvolver ações políticas junto às autoridades de saúde e população para priorizar o controle da doença nos Conselhos Municipais de Saúde (BRASIL, 1997).

Em 1998, frente à situação da TB no país, e considerando a necessidade de ajustes e ampliação do Plano Emergencial, o Conselho Nacional de Saúde, através da resolução 
número 284, de 06/08/98, sugere estabelecer estratégias para um novo plano, que teve as seguintes metas:

- “em três anos (2001) diagnosticar, pelo menos 92\% dos casos esperados;

- tratar com sucesso, pelo menos 85\% dos casos diagnosticados;

- em 9 anos (2007) reduzir a incidência em pelo menos 50\% e a mortalidade em dois terços” (RUFFINO-NETTO, 1999).

O Plano apresentou diretrizes dentre as quais responsabiliza o Ministério da Saúde pelo:

- "estabelecimento das normas, aquisição e abastecimento de medicamentos;

- referência laboratorial e de tratamento;

- coordenação do sistema de informação;

- apoio aos Estados e Municípios, visando maximizar os resultados de políticas públicas”.

Ainda, o Plano trouxe duas inovações onde instituiu como estratégia, repasses financeiros aos municípios.

A primeira tinha como propósito incentivar a intensificação da busca de casos através do exame dos sintomáticos respiratórios, aumentando para $\mathrm{R} \$ 4,20$ o preço de cada baciloscopia realizada a ser paga pelo Ministério de Saúde aos Serviços de Saúde. A segunda incentivava o tratamento e cura dos clientes, instituindo que por ocasião da notificação da alta do doente, a instituição receberia um bônus de R\$ 150,00 (cento e cinqüenta reais) por cada caso curado através do DOTS/TS, ou, um bônus de R\$ 100,00 (cem reais) para cada caso curado através do tratamento auto-administrado (TA).

Reconhecia ainda que, a implementação do programa, frente ao Plano estabelecido, não se reduzia à reprodução criteriosa das prescrições que estão contidas nos manuais de normas técnicas ou no uso dos meios eficazes de prevenção e de cura. Exigia como condição essencial, a articulação e complementaridade de ações dos três níveis de gestão do Sistema 
Único de Saúde (SUS) (União, Estados e Municípios). Definidas as atribuições de cada esfera de governo, caberia ao município identificar prioridades, definir estratégias de trabalho, determinar os recursos necessários e finalmente desencadear os processos de organização e de execução das ações. Nesta fase, componentes políticos deveriam ser considerados, sendo essencial a incorporação do problema da TB como prioridade nos planos municipais de saúde.

Com a criação da Programação Pactuada Integrada (PPI), os municípios passam a pactuar metas, reconhecendo as ações do PCT como de competência da Atenção Básica. Deste modo, tanto os municípios em Gestão Plena da Atenção Básica como os municípios em Gestão Plena do Sistema devem se organizar para assistir ao doente de TB e seus familiares.

Assim, no novo plano, diferentemente do plano emergencial que beneficiava apenas os municípios prioritários, todos os municípios passam a receber o bônus relacionado com a alta por cura do doente. Portanto, o impacto destas ações no comportamento epidemiológico da doença está diretamente relacionado ao modo como estas ações tem sido absorvida pela gestão em âmbito municipal.

Em agosto de 2002, por meio da portaria 1474/GM é reformulado o pagamento de procedimentos relativos ao atendimento de portadores de TB, fixando novos valores de incentivo relacionados à alta por cura. Para os casos curados de forma auto-administrada a instituição receberá R \$ 50,00 e para cada caso curado de forma supervisionada serão pagos R\$ 200,00. Ainda foi adicionado nesta portaria o valor de $\mathrm{R} \$ 50,00$ para cada caso novo notificado.

Para receber tais benefícios, os municípios assinaram um termo de adesão, reafirmando o compromisso com o desenvolvimento das ações do PCT.

Ao final de 2003, por meio de uma nova portaria se distribui nova forma de repasse financeiro, não mais por bônus e sim por valores pré-definidos somente a municípios prioritários. 


\subsubsection{Ações do PCT no Sistema de Saúde do Município de Ribeirão}

\section{Preto- SP.}

o ano de 1995, Ribeirão Preto é eleito no Estado de São Paulo, como um dos municípios prioritários para o combate da TB mediante os critérios para inclusão no Plano Emergencial de Controle da TB proposto em 1994. Dentre os critérios estabelecidos para a priorização dos municípios naquele período, Ribeirão Preto apresentava população acima de 50 mil habitantes; coeficiente de incidência nos últimos cinco anos de 56/100.000 habitantes; taxa média de abandono nos últimos cinco anos de 16\%; cura de 50\% e co-infecção TB/HIV em média 29\% nos últimos dois anos (MUNIZ, 1999).

Sob iniciativa da Divisão de Vigilância Epidemiológica da Secretaria Municipal de Saúde (SMS) foi realizado em dezembro de 1995 o I Fórum Regional de Tuberculose e coinfecção TB/HIV, com objetivo de sensibilizar os profissionais da área da saúde quanto à situação alarmante da TB no país e no município.

Em março de 1996, é criado pela SMS de Ribeirão Preto, o cargo de Coordenação do Programa de Controle da TB, para atender às propostas estabelecidas pela Divisão de Vigilância Epidemiológica. Deste modo, o Município passa a gerenciar o PCT (até então gerenciado pela esfera estadual), atendendo às competências estabelecidas pela CNPS.

A descentralização administrativa e operacional do PCT teve como conseqüência, além da extensão da oferta de serviços, a ampliação gradativa das atribuições municipais, como: compra de equipamentos, insumos, contratação e capacitação de recursos humanos, orientação técnica e supervisão para as equipes das unidades de saúde, em consonância com as normas pré-estabelecidas pela CNPS, com o apoio técnico da DIR XVIII e Centro de Vigilância Epidemiológica (CVE).

Neste mesmo período foi implantada a estratégia de Busca Ativa de Sintomáticos Respiratórios (SR). Ofereceu-se treinamento a profissionais de enfermagem (um enfermeiro e um 
auxiliar de enfermagem de cada Unidade Distrital de Saúde) para identificar o SR na demanda do serviço de saúde e proceder à coleta de escarro.

Com a implantação da Busca Ativa de SR pelas Unidades Básicas Distritais de Saúde (UBDS), houve um acréscimo significativo de baciloscopias de escarro realizadas pelo município e um aumento de casos diagnosticados.

A inclusão do município de Ribeirão Preto no Plano Emergencial exigiu que o mesmo encaminhasse à Fundação Nacional de Saúde (FNS), no ano de 1996, um projeto, no qual constavam metas e o dimensionamento dos recursos. Esse projeto foi aprovado, mas somente em maio de 1997 é que o recurso foi disponibilizado (MUNIZ, 1999).

Uma das metas propostas era melhorar a adesão do doente ao tratamento, diminuindo as taxas de abandono e aumentando os percentuais de cura.

Em julho de 1997, o repasse financeiro procedente do convênio entre município e FNS permitiu implementar as ações do Programa por meio de:

- Aquisição de viatura para o Programa, com vistas a estender a visitação domiciliar para casos novos e avaliação de comunicantes, bem como implantar o DOTS/TS.

- Designação de um motorista para o Programa;

- Aquisição de vale transporte para facilitar o acesso do doente e familiares ao serviço de saúde;

- Aquisição de cestas básicas a serem distribuídas aos clientes com TB como incentivo ao tratamento;

- Estabelecimento de parceria junto à Secretaria do Bem Estar Social, para que o referido órgão distribuísse as cestas básicas utilizando o fluxo já existente; 
- Aquisição de leite integral, para ser distribuído aos clientes submetidos ao DOTS/TS;

- Aquisição de materiais educativos (panfletos, cartazes, álbum seriado, fichas de aprazamento);

- Aquisição de televisão, vídeo, retroprojetor, projetor de slides;

- Confecção de filme educativo;

- Microcomputador para implementação do sistema de informação, etc.

Vale destacar que estes três últimos recursos situam-se no nível central, ou seja, sob a responsabilidade da coordenadoria do PCT no município, e os demais nas cinco UBDS, onde estão as equipes executoras das atividades do PCT.

Uma vez viabilizados todos esses recursos foi possível ampliar a atuação do programa. As equipes avaliaram a possibilidade de implantar o DOTS/TS como estratégia para a redução das taxas de abandono e aumento das taxas de cura. O processo de implantação iniciou-se em setembro de 1997 sendo estendido, gradativamente, para todos os serviços. Esta estratégia vem sendo ampliada anualmente. Em 1998, 20,3\% dos clientes foram supervisionados diariamente no domicílio. Em 1999 a cobertura foi de 31,67\% , em 2000 atingiu 44,9\%, em 2001 alcançou 51,9\%, em 2002 aumentou para 62,6\%, em 2003 foi de 57,7\% e em 2004 73,9\% (Sistema de Informação de Tuberculose - EPI-TB-SMS, 2003). 
Gráfico 1.1 - Cobertura em porcentagem dos casos supervisionados em Ribeirão Preto, nos anos de 1998 a 2004

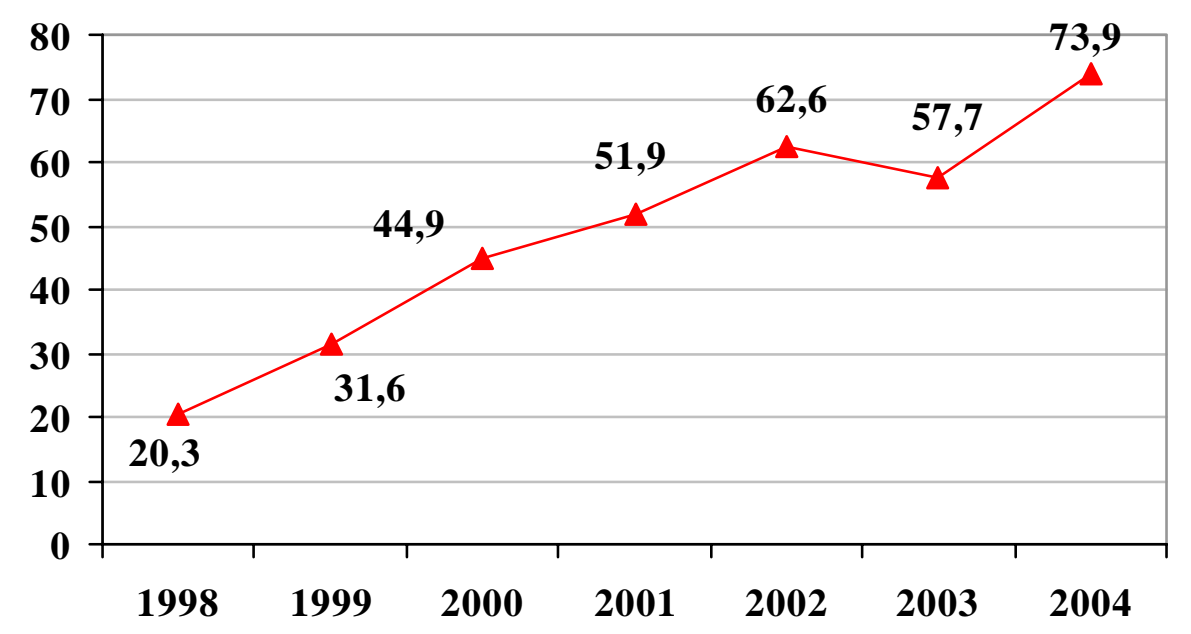

Fonte: Sistema de Informação de Tuberculose- EPI-TB/ SMS. (2005)

A implantação do DOTS/TS associada à reorganização das ações do Programa ocasionou importantes mudanças nos indicadores epidemiológicos da TB. No gráfico a seguir é possível observar que a partir de 1998 há um aumento gradual nos percentuais de cura de TB.

Gráfico 1.2 - Porcentagem de casos curados de tuberculose em residentes no município de Ribeirão Preto, nos anos de 1993 a 2003

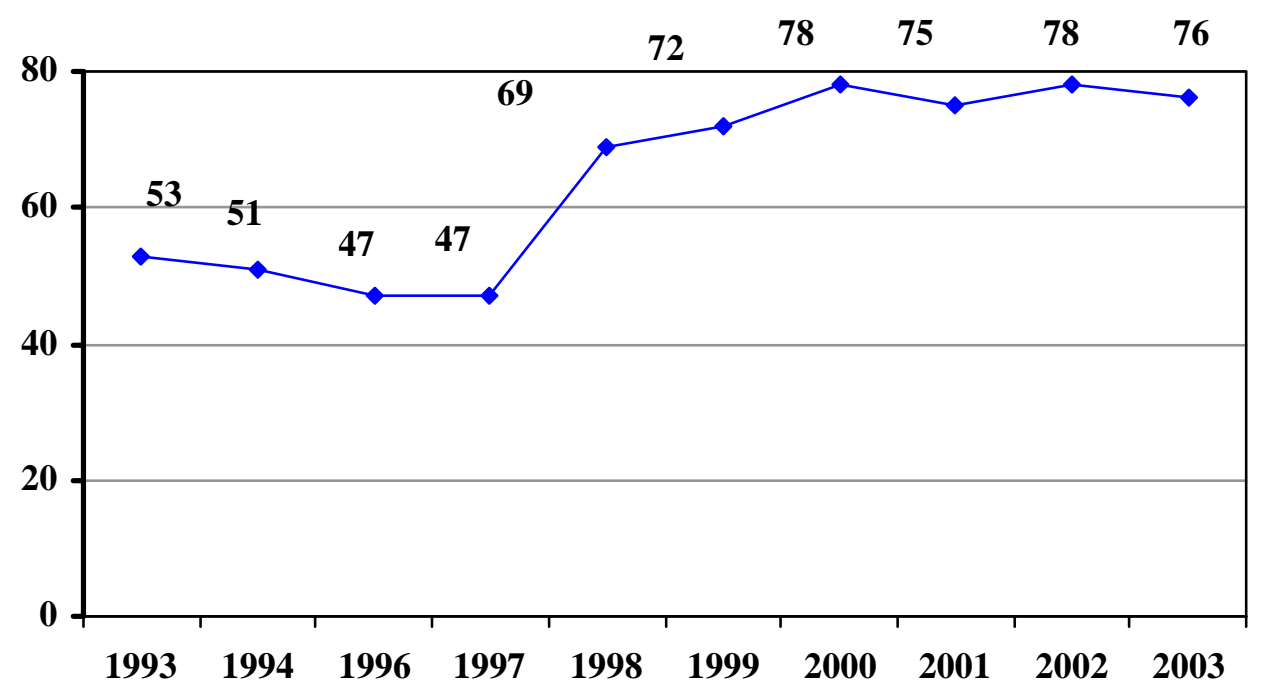

Fonte: Sistema de Informação de Tuberculose- EPI-TB/SMS (2005). 
Ainda esses fatores contribuíram para redução nas taxas de abandono que oscilavam em torno de 15\%, e que diminuíram para 7,8\% no ano de 1999.

Gráfico 1.3 - Porcentagem de abandono de tratamento da tuberculose em residentes no município de Ribeirão Preto, nos anos de 1993 a 2003

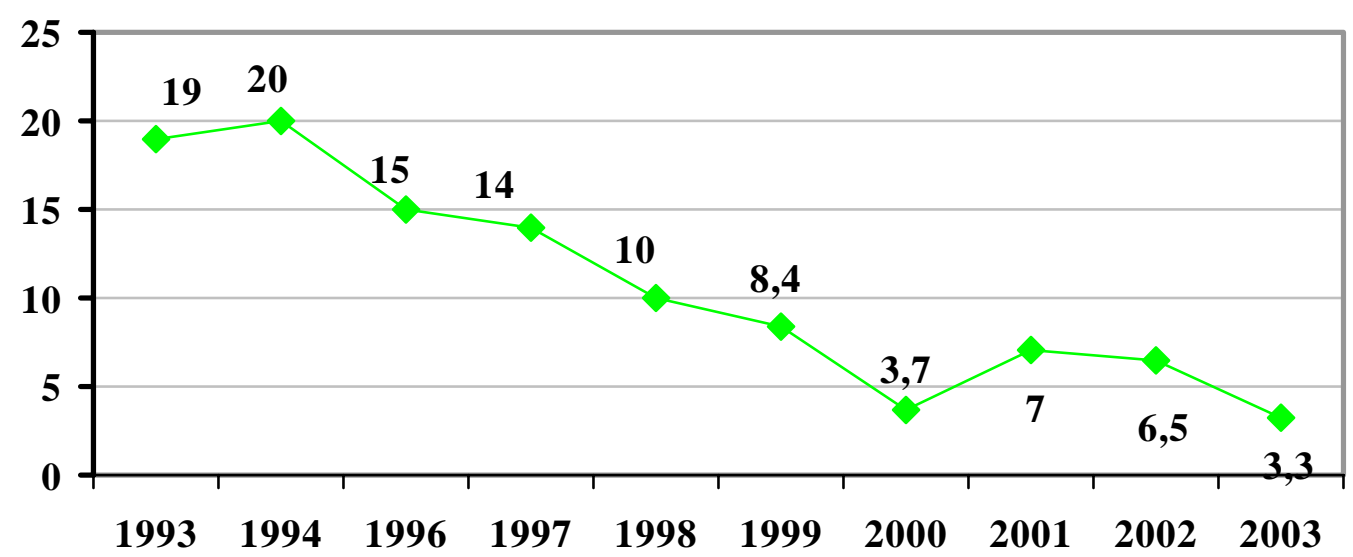

Fonte: Sistema de Informação de Tuberculose- EPI-TB/SMS (2005).

É importante ressaltar que a implementação das ações do PCT e conseqüentes resultados foram determinados frente ao comprometimento político e financeiro dos diferentes níveis de governo (federal, estadual e municipal). O convênio estabelecido entre o município de Ribeirão Preto e o Ministério de Saúde impulsionou o interesse no desencadeamento de medidas que atendessem a uma necessidade política e epidemiológica (MUNIZ, 1999). 


\section{DELIMITAÇÃO DO OBJETO DE ESTUDO}

No município de Ribeirão Preto, atualmente existem ambulatórios de referência para o tratamento da tuberculose (TB) que utilizam o Directly Observed Therapy Short-Course (DOTS) ou Tratamento Supervisionado - TS (DOTS/TS) (Gráfico 2.4).

Gráfico 2.1. Cobertura em porcentagem do DOTS/TS em unidades de saúde, nos anos de 1998 a 2004

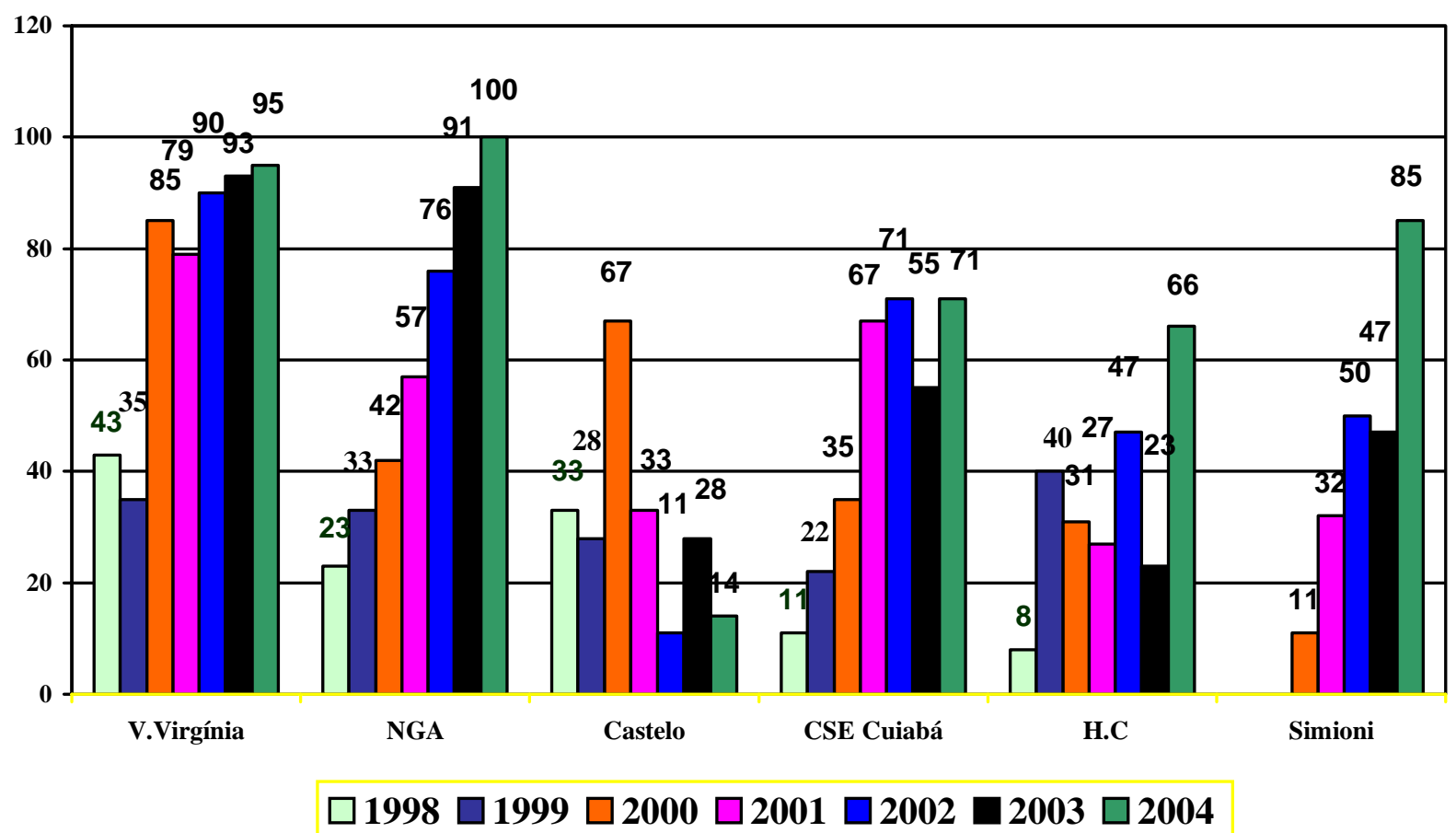

Fonte: Sistema de Informação de Tuberculose- EPI-TB/ SMS (2005).

A implantação do DOTS no município deu-se a partir do esforço conjunto dos diferentes níveis de governo (federal, estadual e municipal) para criar condições estruturais (recursos financeiros, humanos, físicos, organizacionais etc.), as quais, dentre outros fatores, constróem e condicionam o universo da prática da estratégia. 
Nesse sentido, vale lembrar, que a operacionalização do DOTS/TS envolve um processo individual influindo e sendo influenciado pelo próprio serviço de saúde (disponibilidade de recursos, organização do serviço, dentre outros) pelas características culturais e comportamentais tanto dos profissionais como dos doentes/família e, por conseguinte, trazendo para cada local de saúde uma própria dinâmica de trabalho.

No município de Ribeirão Preto, essa prática demanda a visita domiciliar para certificar o uso do medicamento pelo doente e a realização de outras atividades relacionadas ao DOTS/TS (suporte psicológico, apoio para a continuidade do tratamento, esclarecimento de dúvidas sobre o tratamento, intercorrências patológicas dentre outras). Esse deslocamento físico (espacial) depende da existência de recursos permanentes (viaturas), de consumo (combustível e medicamento) e humanos (motorista e profissional de saúde). A disponibilidade desses recursos é importante para o sucesso e a continuidade desse tipo de serviço.

Desse modo, torna-se fundamental o desenvolvimento de estratégias que possibilitem a otimização dos recursos para dispor de melhores condições para a realização das atividades do DOTS/TS.

Acredita-se que os estudos de avaliação relacionados ao desempenho do DOTS/TS no Programa de Controle da Tuberculose (PCT) possam oferecer subsídios para identificar problemas e razões na efetivação das ações e otimização dos recursos, assim como, para o desenvolvimento de intervenções que podem resultar melhoria na elaboração de políticas do planejamento dos recursos, e mais eficiência na prestação de serviço ao doente com TB.

Avaliar o desempenho de um programa ou estratégia de saúde é também uma maneira concreta de reduzir os gastos desnecessários de recursos humanos e materiais em saúde.

Em virtude do exposto, julgou-se necessário a realização deste estudo para conhecer os aspectos operacionais da prática do DOTS/TS, especificamente as condições estruturais do 
programa para inclusão do doente no DOTS/TS, efetivação da atividade principal (Observação da Ingestão da Medicação) no domicílio, duração da visita do profissional ao doente e família, a forma como os recursos disponibilizados são utilizados pela equipe e/ou profissional de saúde responsável pela realização do DOTS/TS no domicílio e as ocorrências que podem interferir tanto na otimização dos recursos quanto na efetivação das atividades do DOTS/TS. 


\section{PRESSUPOSTOS}

O propósito deste estudo foi conhecer e analisar o desempenho dos serviços de saúde que executam o Directly Observed Therapy Short-Course - DOTS ou Tratamento Supervisionado (DOTS/TS) no domicílio a partir dos recursos disponibilizados e da realização das visitas domiciliares para execução das atividades, algumas questões preliminares, portanto, foram necessárias para a elaboração de pressupostos:

- Em que medida o desempenho do DOTS/TS (cobertura, aproveitamento dos recursos, agilidade, monitoração da administração da medicação e tempo gasto por supervisão) está relacionado à estrutura e/ou capacidade (disponibilidade dos recursos humanos e materiais) existente no PCT?

- Em que medida a realização das visitas domiciliares possibilita a execução da Observação da Ingestão da Medicação (atividade principal do DOTS/TS) no domicílio?

Considerando as reflexões sobre as questões apresentadas, parte-se dos seguintes pressupostos:

Os recursos disponibilizados para o DOTS/TS no PCT das unidades de saúde em estudo influenciam na cobertura, aproveitamento dos recursos, agilidade do desempenho, monitoração da administração do tratamento e tempo gasto por supervisão.

A realização das visitas domiciliares no DOTS/TS possibilita a efetivação da Observação da Ingestão Medicamentosa. 


\section{OBJETIVOS}

Geral

Avaliar o “desempenho” dos serviços de saúde que executam o DOTS/TS Domiciliar no Programa de Controle da Tuberculose em Unidades de Saúde do Município de Ribeirão Preto- SP, 2003.

Específicos

1. Construir indicadores de cobertura, aproveitamento dos recursos, agilidade do desempenho, monitoração da administração da medicação e tempo gasto por visita domiciliar nos Programas de Controle da Tuberculose que executam o DOTS/TS;

2. Analisar o desempenho do DOTS/TS no domicílio segundo os indicadores construídos no estudo;

3. Analisar as "ocorrências" durante o DOTS/TS no domicílio. 


\section{QUADRO TEÓRICO}

\section{Avaliação de Serviços e Programas de Saúde}

No desenvolvimento das avaliações em saúde como práticas institucionalizadas, em conjunturas diversas, foram sendo construídas especializações e segmentação com inserções e perfis profissionais próprios. Atividades de avaliação em programas, serviços e tecnologias de saúde podem atualmente ser identificadas diferentes "comunidades" de profissionais inseridos em setores diversos e mais identificados com referenciais político-ideológicos e teóricometodológicos específicos, geralmente vinculados a associações científicas e/ou profissionais que os representam. Entre as mais atuantes serão destacadas aquelas que desenvolvem práticas denominadas de "avaliação tecnológica em saúde", "avaliação, gestão e garantia de qualidade" e "avaliação de programas". Nos países onde essas "comunidades" estão presentes, na dependência de fatores como as características da organização da atenção à saúde, formação e "cultura" profissional, estas se inserem, de maneiras diversificadas na saúde pública, na administração e na gestão ou na medicina (NOVAES, 2000).

A avaliação tecnológica em saúde é aquela que toma como unidade de análise uma tecnologia, de produto ou processo, passível de ser caracterizada na sua dimensão temporal ou espacial. Pressupõe sempre uma circunscrição do objeto relativamente arbitrária para um maior reconhecimento daquela tecnologia (NOVAES, 2000).

Na avaliação, gestão e garantia da qualidade em saúde o conceito de qualidade tem uma função teórica e prática central ao se constituir em um ponto de partida para todo processo (DONABEDIAN, 1980). Ainda que interligadas, tanto a avaliação quanto a garantia e a gestão da qualidade têm seus referenciais teóricos e metodológicos específicos.

A avaliação de programas em saúde tem como foco de análise os programas, considerados aqui no sentido que é utilizado pela literatura norte-americana, como processos 
complexos de organização de práticas voltadas para objetivos específicos (NOVAES, 2000). Deste modo, são considerados como programas, tanto aquelas propostas voltadas para a realização de um macro objetivo, como a implantação de formas de atenção para populações específicas e que envolvem instituições, serviços e profissionais diversos, como as atividades desenvolvidas em serviços de saúde, que têm por objetivo prestar um determinado tipo de atendimento para uma dada clientela.

Segundo Donabedian (1980) a avaliação dos programas deve levar em conta as atividades relacionadas à manutenção e/ou crescimento da organização, incluindo financiamento, recursos humanos, população atendida, aceitação e apoio da comunidade, relações com outros setores de saúde e outras características do ambiente da organização. O autor desenvolveu três enfoques principais para a avaliação da qualidade da atenção médica (Estrutura, Processo e Resultado). A utilização desses três elementos é possível porque existe uma relação funcional fundamental entre eles. Isto significa que as características estruturais dos locais onde se presta a assistência têm uma propensão a influir sobre o processo da atenção diminuindo ou aumentando a qualidade. De forma semelhante, as mudanças no processo de atenção, incluindo as variações da qualidade, influenciarão no efeito da atenção sobre o estado de saúde na sua definição mais ampla.

Tanaka e Melo (2001) utilizam a concepção de Donabedian modificada para a avaliação de programas. Os componentes E-P-R apresentam-se interdependentes, abertos e permeáveis ao usuário do “sistema”, que faz parte integrante do processo, influindo e sendo influenciado por esse, e por conseguinte trazendo para dentro dos componentes as características do contexto imediato. O resultado é a característica do cliente/usuário que foi modificada na interação do processo.

Starfield (2002) utiliza o mesmo referencial para avaliar a Atenção Primária no Sistema de Saúde. A autora refere que as características individuais dentro de cada 
componente diferem de lugar para lugar e de época para época, mas cada sistema de serviços de saúde possui uma estrutura (ou capacidade) que consiste nas características que possibilitam a oferta de serviços, os processos (ou desempenho) que envolvem tanto ações por parte dos profissionais de saúde nos sistemas como as ações das populações e dos clientes, e o resultado é refletido em vários aspectos do estado de saúde. Estes componentes interagem com o comportamento individual e são determinados tanto por ele como pelo ambiente social, político, econômico e físico em que o sistema de serviços de saúde existe.

Para possibilitar uma maior compreensão da temática em estudo é importante trazer algumas definições do termo avaliação. Nesse sentido, Tanaka e Melo (2001) referem que avaliar significa expor um valor assumido a partir do julgamento realizado com base em critérios previamente definidos. Ao avaliar, identificam-se instrumentos e referências para emitir um juízo de valor, inerente ao processo. A avaliação deverá ser também compreendida como uma estratégia para decidir como enfrentar e resolver problemas.

Deste modo, a avaliação de programas pode ser também entendida como avaliação para decisão, cujo objetivo dominante é de se constituir em um elemento efetivamente capaz de participar de processos de tomada de decisão, ou seja, que produza respostas para perguntas colocadas por aqueles que vivenciam o objeto avaliado. O enfoque priorizado, aquele que orienta os principais objetivos, é o do reconhecimento do objeto, na profundidade necessária para a sua adequada compreensão, identificação dos problemas e alternativas de equacionamento possíveis (NOVAES, 2000).

Umas das orientações gerais para começar um processo de avaliação é a avaliação do processo ou das atividades desenvolvidas e baseadas em padrões. A partir daí, pode-se desenvolver a avaliação de estrutura e/ou resultado. Ao se iniciar pelo processo, isto é, pelo núcleo de atividades essenciais que caracterizam o programa, a análise e o julgamento dos indicadores de estrutura (condições e recursos existentes) e de resultado (modificação obtida 
na clientela) terão maior utilidade na tomada de decisões. A avaliação que busca identificar a inter-relação e a interdependência entre a E-P-R, é a “real” avaliação de serviços, sistemas ou programas (TANAKA; MELO, 2001).

Quando se relacionam e associam as ações/atividades com as repercussões alcançadas no programa de saúde, torna-se possível avaliar a efetividade das ações e, consequentemente, decidir por alternativas que produzam os melhores resultados. Ao relacionar e associar as ações/atividades com a disponibilidade de recursos humanos, materiais ou tecnológicos do programa, será possível avaliar o grau de otimização desses recursos. Essa relação também permite a adequação tecnológica da oferta, possibilitando decisões direcionadas a uma ampliação mais racional de recursos de investimento para uma incorporação tecnológica mais adequada às características da demanda (TANAKA; MELO, 2001).

Segundo Favaro e Ferris (1988), a avaliação de programas de saúde busca melhorar a execução do programa - por meio do incremento da sua efetividade e sua eficiência, e/ou proporcionar elementos para decidir se este deve continuar ou pode ser reproduzido. A avaliação também deve ser capaz de gerar informações necessárias para distribuir melhor a infra-estrutura e os recursos disponíveis entre as atividades já empreendidas ou entre as que se pretendem desenvolver mais para frente, e para tomar decisões dentro do ciclo de planejamento, desenvolvimento, implantação e operacionalização do programa no futuro. Esta modalidade de avaliação, denominada avaliação de processo, em algum momento deve complementar-se com uma avaliação do impacto do programa.

Conforme Donabedian (1980), a avaliação de programa deve responder pelo desempenho das sub-unidades organizacionais, cuja função é suprir, apoiar, facilitar e potencializar as atividades das unidades e do pessoal que proporcionam cuidados de saúde diretamente aos usuários. O sucesso, ou o fracasso são feitos de momentos de verdade que cada usuário vivencia, e que difere de acordo com características individuais, sócio- 
econômicas e culturais, o tipo de instituição onde são tratados, a qualidade do serviço que recebeu ou o tipo de agravo.

Na abordagem de avaliação proposta por Donabedian (1980) o autor define a estrutura como as características relativamente estáveis dos provedores de atenção, dos instrumentos e recursos que dispõem e dos lugares físicos e organizacionais onde trabalham. Incluem os recursos humanos, físicos e financeiros necessários para proporcionar atenção médica. Abrange o número, distribuição e qualificação dos profissionais de saúde, assim como, o número e tamanho dos equipamentos, disposição geográfica dos hospitais e outras instalações, características da população (demográficas, sociais, econômicas e de localização) e horário de atenção ao doente para consulta médica e para tratamento.

O processo é definido como uma série de atividades realizadas pelos e entre os profissionais e clientes. O processo inclui os atributos de continuidade, coordenação, trabalho em equipe, seqüência apropriada da assistência e forma de atendimentos dos profissionais ao doente.

O resultado é apreendido como um significado da mudança no estado atual da saúde do doente que é atribuído aos cuidados de saúde anterior e a satisfação dos profissionais de saúde.

Considera-se que a abordagem que busca avaliar o sistema, serviço ou programa de saúde a partir do componente processo e a partir deste identificar a inter-relação e a interdependência com a estrutura e resultado é aquela que inicialmente parece ser a mais difícil.

Considera-se que a natureza intrínseca de alguns programas de saúde e das tecnologias adotadas exige uma maior atenção para a avaliação das ações/atividades do programa (processo) proporcionadas pelos profissionais de saúde na assistência ao doente. 
No contexto da avaliação de Programas de Saúde, Tanaka e Melo (2001) consideram também importante referir a utilidade da separação dos indicadores de E-P-R com base nos pressupostos conceituais da chamada avaliação da qualidade (DONABEDIAN, 1980). Esta forma de avaliação oferece vantagem, permitindo uma classificação preliminar dos indicadores frente às características dos serviços com as quais estão primordialmente relacionados.

A escolha de um indicador de estrutura pode auxiliar na tomada de decisão de investimento e/ou de provimento de recursos necessários para o sistema, serviço ou programa. A escolha de um indicador de processo está direcionada à tomada de decisão referente à otimização e/ou utilização racional da dinâmica implementada, enquanto a escolha de um indicador de resultado está direcionada à tomada de decisão de prosseguimento ou não da intervenção realizada.

O objetivo final é abordar os três componentes: E-P-R. Qualquer que seja o componente inicial selecionado na avaliação é desejável que se analise a inter-relação e a interdependência dos três componentes, que facilita responder às hipóteses formuladas e propicia maior efetividade nas decisões que serão tomadas.

A iniciativa para avaliar um programa de saúde passa pela necessidade de analisar e julgar algo (ação, atividade, programa, serviço de saúde) com a finalidade de conhecer e modificar essa situação mediante a tomada de novas decisões.

Cabe, dizer então, que a escolha da abordagem e o componente inicial para começar o processo de avaliação num sistema, serviço ou programa de saúde depende do objeto que se pretende avaliar e da utilidade de seus resultados. 


\section{METODOLOGIA}

Trata-se de um estudo exploratório realizado no município de Ribeirão Preto que inclui quatro PCT que desenvolvem a estratégia Directly Observed Therapy Short-Course DOTS ou Tratamento Supervisionado - TS (DOTS/TS) no domicílio em diferentes distritos do município: Centro de Referência em DST/AIDS e Tuberculose Dr. José Roberto Campi Vila Virgínia; Unidade Básica Distrital de Saúde Centro de Saúde Escola - Sumarezinho; Unidade Básica Distrital de Saúde Alexander Fleming - Simioni e Núcleo de Gestão Ambulatorial - NGA-59.

Figura 6.1 - Distribuição geográfica dos Distritos de Saúde do Município de Ribeirão Preto

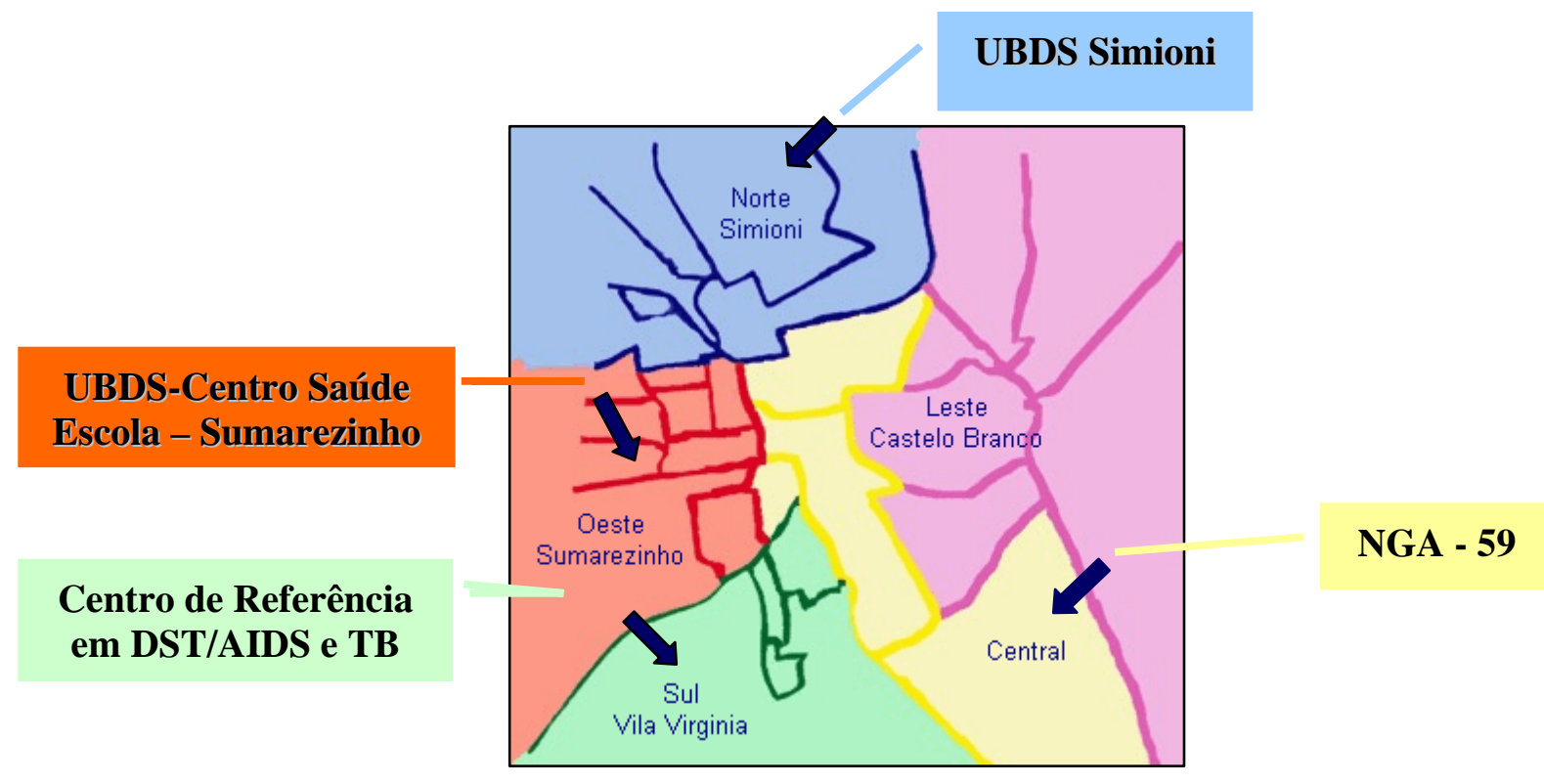

A coleta de dados foi realizada durante o mês de julho de 2003. O critério adotado para a escolha do mês foi a uniformidade na incidência notificada de casos de TB dos clientes residentes no município de Ribeirão Preto nos três anos anteriores ao estudo. 
Tendo em vista o objetivo da pesquisa, procurou-se uma abordagem teóricometodológica capaz de representar as características principais da operacionalização do DOTS/TS nos PCT. Nesse sentido, utilizou-se como referencial metodológico os enfoques básicos para avaliação da qualidade da atenção médica Estrutura-Processo-Resultado proposto por Donabedian (1980) e modificado por Tanaka e Melo (2001) e Starfield (2002).

Analisou-se especificamente aspectos operacionais do DOTS/TS no domicílio de modo a avaliar a efetividade das ações e a otimização dos recursos. Foram considerados e analisados alguns elementos da estrutura, uma vez que a execução do DOTS/TS no domicílio não é possível sem uma estrutura mínima que permita desenvolver as atividades inerentes ao tratamento do doente de TB. No componente processo foi considerada apenas a atividade essencial do DOTS/TS (visita domiciliar para Observação da Ingestão da Medicação).

Foram acompanhados todos os clientes que, no período em estudo, receberam DOTS/TS no domicílio, assim como aqueles que foram incluídos na supervisão durante a coleta de dados.

\section{Descrição das Unidades de Saúde que desenvolvem o DOTS/TS}

Centro de Referência em DST/AIDS e Tuberculose Dr. José Roberto Campi - Vila Virgínia. Oferece atendimento básico e concentra algumas especialidades médicas, que atendem à demanda oriunda da área de abrangência distrital. Nesta área há três Unidades Básicas de Saúde que atendem, aproximadamente, 82.239 habitantes.

O PCT está constituído por uma equipe formada por um profissional médico e duas auxiliares de enfermagem no período da manhã.

Unidade de Referência de nível secundário Núcleo de Gestão Ambulatorial (NGA-59) ou ambulatório de especialidades. Caracteriza-se por ser um serviço municipalizado, fruto da 
fusão de um centro de saúde estadual e um antigo PAM-I do INAMPS. Constitui referência para assistência de maior complexidade para os municípios da DIR XVIII - Direção Regional de Saúde. Não oferece atendimentos básicos. Atende no período diurno, de segunda à sextafeira. É responsável pelo atendimento de clientes com TB em uma área de aproximadamente 190.000 habitantes.

A equipe do PCT é constituída por uma médica infectologista, uma enfermeira, duas auxiliares de enfermagem (teoricamente uma responsável pela supervisão domiciliar e outra pela pré e pós consulta). Cabe ressaltar que a equipe de enfermagem exerce outras funções tanto dentro das diversas atividades do PCT (pré e pós-consulta) quanto dentro do próprio serviço de saúde. Também assume, eventualmente, o DOTS/TS de outros PCT do município, em caso de férias e licença de funcionários designados para tal atividade.

Quando necessária a internação de s com TB, seja por critérios clínicos ou sociais, essas unidades referidas com o Abrigo Ana Diederichsen.

\section{Unidade Básica Distrital de Saúde Centro de Saúde Escola - Sumarezinho. Oferece} atendimento básico e concentra algumas especialidades médicas que atendem à demanda oriunda da área de abrangência distrital. Nessa área há sete Unidades Básicas de saúde e quatro núcleos do Programa de Saúde da Família que atendem aproximadamente 139.987 habitantes.

O PCT é desenvolvido nos período da manhã e da tarde. A equipe está constituída por dois médicos infectologistas, ambos responsáveis tanto pelo PCT quanto pelo Programa de DST-AIDS (um no período da manhã e o outro, no período da tarde), uma enfermeira, dois auxiliares de enfermagem (um responsável pela supervisão domiciliar e outro, pela pré e pós consulta do serviço de Moléstias Infecciosas que inclui o PCT). 
Unidade Básica Distrital de Saúde Alexander Fleming - Simioni. Oferece atendimento básico e concentra algumas especialidades médicas, que atendem à demanda oriunda da área de abrangência distrital. Nessa área há sete Unidades Básicas de Saúde que oferecem atendimento a aproximadamente 96.402 mil habitantes. O PCT funciona no período da manhã e está constituído por um médico, uma enfermeira e um auxiliar de enfermagem.

Os PCT das Unidades de Saúde contam com o apoio da equipe de Vigilância Epidemiológica, do Serviço Social, de transporte e farmacêutico. Vale acrescentar que há também sala de vacinas onde é realizada a BCG rotineiramente. O laboratório de referência para análise do exame de baciloscopia de escarro é a UNAERP, e diariamente é garantido serviço de transporte do material das unidades para o laboratório. O Instituto Adolfo Lutz é responsável pela supervisão e controle de qualidade do laboratório conveniado.

\subsection{Construção de Indicadores.}

Na construção dos indicadores levou-se em consideração a importância da análise da inter-relação e interdependência dos componentes. Nesse sentido, os indicadores foram construídos na relação de variáveis entre a Estrutura e Processo. Foram selecionados alguns elementos de cada componente.

Ressalta-se que os elementos da Estrutura correspondem a alguns atributos materiais e humanos que possibilitam o DOTS/TS no domicílio, tais como: condução (viatura e motorista) e o profissional de saúde responsável pela supervisão do tratamento do cliente no domicílio.

No componente processo foi considerada a atividade essencial do DOTS/TS: visita domiciliar para Observação da Ingestão da Medicação. 


\section{Indicadores:}

1.- Cobertura. Variável quantitativa contínua medida por meio de uma proporção que identificou o número de doentes cujo tratamento de TB foi supervisionado pelo profissional de saúde.

Definição operacional: proporção de doentes em DOTS/TS em relação ao total de doentes em tratamento de TB.

\section{$\mathbf{C}=\underline{\mathrm{N}^{\mathrm{o}} \text { de clientes em DOTS/TS }}$}

Total de clientes em tratamento de TB

$\mathbf{C}=\underline{\mathrm{N}^{\circ} \text { de clientes em DOTS/TS no Domicílio }}$

Total de clientes em tratamento de TB

2.- Aproveitamento dos recursos. Variável quantitativa contínua medida por meio de proporção que identificou o tempo de aproveitamento dos recursos nos serviços de saúde que executam o DOTS/TS no Domicílio.

Definição operacional: proporção de tempo gasto dos recursos para o DOTS/TS em relação ao tempo disponível dos recursos para o DOTS/TS.

$$
\mathbf{A p}=\frac{\text { Tempo gasto dos recursos }}{\text { Tempo disponível dos recursos }}
$$

3.- Agilidade do desempenho. Variável quantitativa discreta que identificou o número médio de visitas domiciliares por hora disponível e por hora gasta dos recursos.

Ag $=\mathrm{N}^{\mathrm{o}}$ de visitas domiciliares realizadas por hora disponível dos recursos do DOTS/TS

$\mathbf{A g}=\mathrm{N}^{\mathrm{o}}$ de visitas domiciliares realizadas por hora gasta dos recursos do DOTS/TS

4.- Monitoração da administração da medicação. Variável quantitativa discreta medida por meio de uma proporção que permitiu identificar a eficiência do DOTS/TS em relação à Observação da Ingestão da Medicação efetivamente realizada. 
Definição operacional: proporção de número de visitas domiciliares com Observação da Ingestão da Medicação em relação ao número de visitas domiciliares realizadas para Observação da Ingestão da Medicação.

$\mathbf{O I M}=\underline{\mathrm{N}^{o} \text { de visitas domiciliares com Observação da Ingestão da Medicação }}$ $\mathrm{N}^{\mathrm{o}}$ de visitas domiciliares para Observação da Ingestão da Medicação

5.- Tempo gasto por visita domiciliar. Variável quantitativa contínua que estimou o tempo médio utilizado pelo profissional de saúde em cada visita domiciliar realizada no DOTS/TS. Definição operacional: tempo disponível e tempo gasto dos recursos para o DOTS/TS em relação ao total de visitas domiciliares

\section{Td = Tempo disponível dos recursos para o DOTS/TS (min) \\ Total de visitas domiciliares}

\section{$\mathbf{T g}=\underline{\text { Tempo gasto dos recursos para o DOTS/TS (min) }}$ \\ Total de visitas domiciliares}

\subsection{Coleta de dados}

A coleta realizou-se simultaneamente nas quatro unidades de saúde. Para se alcançar tal propósito constituiu-se uma equipe de trabalho de campo formada por três alunas de iniciação científica e duas alunas de doutorado. Previamente foi desenvolvido um período de treinamento da equipe com o propósito de uniformizar critérios para a coleta de dados. Assim, antes do trabalho de campo, aplicaram-se os instrumentos elaborados (estudo piloto), com o intuito de identificar dúvidas e/ou dificuldades de ordem operacional pela equipe. Destaca-se que a responsável pela pesquisa ficou na função de supervisora durante o período de coleta de dados.

Os dados relacionados ao Desempenho dos serviços de saúde que executam o DOTS/TS no domicílio foram coletados pela Técnica de Observação Sistemática por meio do 
acompanhamento das visitas domiciliares realizadas pelo profissional de saúde responsável pela supervisão do tratamento do doente com TB no domicílio. Utilizou-se um formulário específico para à obtenção de dados sobre: cobertura, aproveitamento dos recursos do DOTS/TS, agilidade, monitoração da administração da medicação e tempo gasto por visita domiciliar.

Em relação ao segundo objetivo específico - ocorrências durante o DOTS/TS no domicílio estas foram categorizadas em função daquelas que estiveram relacionadas ao serviço de saúde e daquelas relacionadas ao doente, família e comunidade. As ocorrências foram definidas como eventos inesperados durante a realização da visita de supervisão no período em estudo.

\subsection{Características da população em estudo}

Realizou-se a caracterização dos doentes supervisionados no domicílio durante o estudo de acordo com as seguintes variáveis: sexo, idade, escolaridade, ocupação, diagnóstico, esquema de tratamento, condição de tratamento e doença associada (AIDS).

O total de doentes foi 47 , dos quais 19 do sexo feminino e 28 do sexo masculino. A maior concentração de doentes (24) estiveram na faixa etária de 20 a 49 anos, seguido da faixa de 50 a mais (19), três (3) menores de 9 anos e um (1) incluído na faixa de 10 a 19 anos. Quanto à escolaridade, 26 doentes apresentaram ensino fundamental incompleto, cinco (5), ensino fundamental completo, quatro (4), ensino médio incompleto; quatro (4), sem escolaridade e cinco (5), doentes sem informação.

Em relação à ocupação, treze (13) estavam desempregados, sete (7) realizavam atividades do lar, seis (6) eram trabalhadores braçais, seis (6) eram aposentados, três (3) eram estudantes, oito (8) realizavam outras atividades, dois (2) sem informação e um (1) sem 
ocupação. Apenas um (1) doente realizava atividades de nível médio (motorista, auxiliar de limpeza, dentre outros).

Quanto à forma clínica e condição de tratamento, 43 doentes apresentaram a forma pulmonar e quatro (4) extra pulmonar, 35 receberam tratamento pela primeira vez, seis (6) foram retratamento após abandono, cinco (5) receberam retratamento por recidiva e um (1) recebeu retratamento por falência.

Em relação ao esquema de tratamento, 37 receberam o Esquema 1; três (3), Esquema reforçado; três (3), Esquema III e quatro (4), esquema especial. Do total de doentes acompanhados, sete (7) apresentaram doença associada (AIDS).

Os dados foram coletados da Ficha de Notificação e do registro de acompanhamento diário da ingestão medicamentosa. Os prontuários dos clientes foram utilizados como fonte de dados complementar.

\subsection{Análise dos Resultados}

A avaliação do desempenho foi realizada na relação de variáveis selecionadas para o estudo. Quando realizada a análise dos indicadores de aproveitamento de recursos do DOTS/TS e agilidade entre os PCT, esta foi complementada em função da análise por variável a partir da média e do intervalo de confiança.

A determinação das diferenças entre os PCT foi realizada em função da análise de variância aplicando o teste de Tukey, considerando 5\% o nível de significância $(\mathrm{p}<0,05)$ com o auxílio do Programa Estatístico Graphpad Instat, versão 3.01.

Os PCT foram nomeados por de uma letra para melhor localização dos mesmos nos resultados e discussão de dados, como segue:

(A). Unidade Básica Distrital de Saúde Dr. Marco Antônio Sahão - Vila Virgínia.

(B). Unidade Básica Distrital de Saúde Centro de Saúde Escola - Sumarezinho.

(C). Unidade de Referência Núcleo de Gestão Ambulatorial - NGA-59.

(D). Unidade Básica Distrital de Saúde Alexander Fleming - Simioni . 
Para estimar o número de doentes em tratamento de TB e o número de doentes que receberam DOTS/TS no período em estudo para a análise da cobertura, utilizou-se como critério a data de início do tratamento da TB e a condição de tratamento (supervisionado ou não) considerado na Ficha de Notificação da Vigilância Epidemiológica de cada PCT das unidades de saúde em estudo.

Alguns doentes em DOTS/TS no domicílio estudados não estavam considerados no total de casos registrados na Vigilância Epidemiológica (VE) das unidades de saúde no ano de 2003, uma vez que alguns eram casos notificados no ano de 2002 e outros eram supervisionados por uma unidade diferente daquela que notificou o caso.

No PCT (A), um dos doentes não considerados estava recebendo tratamento na UETDI. No PCT (B) houve um caso de retratamento após abandono notificado no ano 2002. No PCT (C) houve um doente supervisionado pela unidade, porém, o caso tinha sido notificado em outra unidade de saúde; dois casos foram notificados no ano de 2002. No PCT (D), um caso de retratamento após abandono foi notificado no ano de 2002.

Para auxiliar a análise dos resultados foram consideradas algumas variáveis de contexto relacionadas às unidades de saúde (área de abrangência), e aquelas relacionadas aos PCT (disponibilidade dos recursos do DOTS/TS, organização do DOTS/TS e férias dos funcionários).

Tabela 6.1 - Unidades Básicas e população estimada para as unidades de saúde no ano de 2004, segundo área de abrangência

\begin{tabular}{|c|c|c|}
\hline Unidades de saúde & UBS por unidade & População \\
\hline UBDS C.S.E & 11 (4 PSF) & 139,987 \\
\hline NGA-59 & $\begin{array}{l}\text { Ambulatório de } \\
\text { Especialidade }\end{array}$ & 190,00 \\
\hline UBDS Simioni & 7 & 96,402 \\
\hline
\end{tabular}




\begin{tabular}{llc}
\hline UBDS Vila Virgínia & 3 & 82,239 \\
\hline
\end{tabular}

Fonte: Censo 2000 (IBGE) estimativa DATASUS de Divisão de Planejamento em Saúde da Secretaria Municipal de Saúde.

Tabela 6.2 - Disponibilidade dos recursos para realizar o DOTS/TS no domicílio

\begin{tabular}{cccc}
\hline Unidade de Saúde & Viatura & Motorista & Profissional de saúde \\
\hline (A) & $\mathbf{x}$ & $\mathbf{x}$ & $\mathbf{x}$ \\
(B) & $\mathbf{x}$ & $\mathbf{x}$ & $\mathbf{x}$ \\
(C) & $\mathbf{x}$ & $\mathbf{x}$ & $\mathbf{x}$ \\
(D) & & & $\mathbf{x}$ \\
\hline
\end{tabular}

O PCT (C) divide viatura e motorista com o PCT (D) duas vezes por semana, ficando posteriormente na dependência da condução da VE da própria unidade de saúde.

\section{Organização do DOTS/TS}

Todos os PCT das unidades em estudo, com exceção do PCT (A), utilizam critérios para supervisionar o tratamento do doente tais como: os fatores de risco, disponibilidade de recursos materiais e humanos no serviço de saúde, dentre outros.

A freqüência das visitas domiciliares para supervisão do tratamento do doente ocorre em função da situação e/ou evolução e grau de compromisso deste no processo de tratamento. Outros fatores, como a demanda de clientes para serem supervisionados no programa, também influenciam na definição da freqüência da supervisão, tanto dos clientes que iniciam a supervisão, quanto daqueles que já se encontram finalizando a primeira fase do tratamento. 
O PCT (A) adota o DOTS/TS universal (supervisionar 100\% dos casos de TB). As visitas domiciliares são realizadas diariamente a todos os doentes.

Alguns PCT disponibilizam alguns dias da semana para executar outras atividades não relacionadas ao DOTS/TS tais como coleta de sangue e entrega de incentivos. 


\section{RESULTADOS E DISCUSSÃO}

\section{Desempenho dos serviços de saúde que executam o DOTS/TS Domiciliar no Programa de Controle da Tuberculose}

\section{Cobertura}

O total de clientes que receberam tratamento de tuberculose (TB) no período em estudo (julho/2003) foi 77, dos quais 70,1\% foram supervisionados. Do total de clientes em DOTS/TS 61\% receberam supervisão no domicílio.

Os Programas de Controle de Tuberculose (PCT) (A) e (C), apresentaram maior cobertura conforme mostra a Tabela 7.1.

Tabela 7.1 - Cobertura do DOTS/TS nos PCT das unidades de saúde do município de Ribeirão Preto, julho, 2003

\begin{tabular}{cccccc}
\hline PCT & $\mathbf{N}^{\mathbf{0}} \mathbf{d e}$ & \multicolumn{2}{c}{ DOTS/TS } & \multicolumn{2}{c}{ DOTS/TS no domicílio } \\
\cline { 3 - 6 } & casos & $\mathrm{N}^{\mathbf{0}}$ & $\%$ & $\mathrm{~N}^{\mathbf{y}}$ \\
\hline (A) & 14 & 13 & 92,8 & 11 & $\%$ \\
(B) & 31 & 20 & 64,5 & 16 & 80.6 \\
(C) & 21 & 17 & 80.9 & 15 & 88.2 \\
(D) & 11 & 4 & 36.4 & 5 & 125.0
\end{tabular}

Segundo o estudo realizado por Muniz (1999) sobre o DOTS/TS no controle da TB no município de Ribeirão Preto - São Paulo, quase todas as equipes de saúde dos PCT realizam o DOTS/TS apenas para aqueles clientes que apresentaram fatores de risco. A autora refere que a conduta adotada se deve ao fato de que os PCT não conseguem oferecer tal procedimento para toda a população de clientes com TB.

Acredita-se que esta situação se deve principalmente à estrutura disponível do programa, uma vez que privilegiou-se o domicílio como local de atuação para a prática do DOTS/TS, em função da pactuação estabelecida entre o serviço de saúde e os clientes/famílias de TB. Nesse sentido, a supervisão do doente no domicílio só será possível 
enquanto recursos (tempo do profissional de saúde responsável pela visita domiciliar e horas disponíveis da viatura) forem disponibilizados. Em função de como forem distribuídos tais recursos, a equipe de saúde terá condições de organizar o DOTS/TS no domicílio para todos os clientes com TB ou para apenas uma parcela deles.

Ressalta-se que a viatura e o motorista são indispensáveis quando a equipe do PCT adota a modalidade da supervisão do tratamento no domicílio. No entanto, a supervisão do doente com TB pode ser realizada na unidade de saúde ou sob outras modalidades e/ou estratégias de organização da assistência, tais como Programa Saúde da Família (PSF) e Programa do Agente Comunitário de Saúde (PACS).

Quando o DOTS/TS é oferecido apenas para alguns clientes, a equipe de saúde adota alguns critérios de inclusão que estão relacionados ao perfil do doente (alcoólatra, usuário de drogas, doente que não valoriza o tratamento, que mora sozinho, dentre outros), ao tratamento anterior por recidiva e/ou abandono, à forma clínica da doença (prioridade TB pulmonar) e à área geográfica (distância do domicílio em relação ao serviço de saúde).

De acordo com o II Consenso Brasileiro de TB (2004), são prioridades para qualquer medida de implementação do DOTS/TS os adultos com diagnóstico de TB pulmonar bacilifera; clientes pertencentes aos grupos de maior risco de abandono de tratamento tais como: usuários de drogas, alcoólatras, moradores de rua ou que residem em comunidades fechadas como prisões, asilos, casas de repouso e hospitais psiquiátricos, clientes sob esquema de retratamento e portadores de formas multirresistentes.

Na Califórnia, a maioria dos departamentos de saúde estão orientando o DOTS/TS para pessoas de alto risco de não adesão argumentando que o DOTS/TS universal é mais caro que o auto-administrado e os sistemas de saúde têm poucos recursos (SNYDER; CHIN, 1999). 
Considera-se que as características da estrutura do PCT, assim como, do próprio serviço de saúde influenciam na definição da cobertura e na organização do DOTS/TS, uma vez que a estrutura é que propicia a prestação dos serviços no sistema de saúde (STARFIELD, 2002).

Quando há disponibilidade de recursos é importante também avaliar se estes são estáveis ou são influenciados pelo contexto imediato, em que se desenvolvem as atividades do DOTS/TS com o intuito de identificar o quanto podem influenciar na cobertura, assim como no próprio desempenho da estratégia.

Morrone et al. (1999) referem que só os serviços bem estruturados e com toda a equipe motivada devem realizar o DOTS/TS. Os serviços com atendimento precário, portanto, só devem iniciar o DOTS/TS após profunda reformulação, pois podem trazer como conseqüência a desmoralização desta forma de acompanhamento do tratamento de TB.

A infra-estrutura insuficiente é apontada no relatório da WHO (2004) como um dos principais obstáculos para implementação da estratégia, melhora da cobertura e detecção de casos em países com maior número de casos de TB.

Num contexto mais amplo, contemplando a estratégia DOTS com seus cinco elementos fundamentais, Ruffino-Netto (2001), refere que adotar a estratégia é forçar uma reflexão sobre a estrutura e o processo dos serviços de saúde em geral. No município de Ribeirão Preto - São Paulo, a implementação das ações do PCT e conseqüentes resultados (importantes mudanças nos indicadores epidemiológicos da TB) foram determinados frente ao comprometimento político e financeiro dos governos Federal, Estadual e Municipal, e pela reorganização das ações do Programa.

Porém, cabe ressaltar que o PCT da Secretária Municipal de Saúde (SMS) continuamente enfrenta problemas de recursos para a realização das atividades do DOTS/TS tais como a disponibilidade de viatura e motorista e incentivos, dentre outros. O programa 
conta um uma viatura, mas não dispõe de motorista, uma vez que este recurso é gerenciado pela Divisão de transporte do município de Ribeirão Preto. Deste modo, os PCT (C) (D), para os quais foram designados tais recursos, ficam na dependência do motorista para realizar DOTS/TS no domicílio do doente. Este fato, algumas vezes, causa uma instabilidade de horário e tempo disponível da viatura e motorista, situação que geralmente se torna um obstáculo para que a equipe e/ou profissional de saúde, responsável pela execução do DOTS/TS defina o número de clientes que será possível supervisionar, assim como, para a realização das atividades atribuídas ao PCT e ao próprio serviço de saúde. No PCT (A) utilizam-se os recursos (viatura e motorista) do Programa DST-AIDS e no PCT (B), do próprio serviço de saúde.

Todos os PCT contam com um profissional de saúde para realizar as atividades de supervisão no domicílio, porém, a conformação das equipes de saúde é diferente de uma unidade de saúde para outra. O PCT (D) diferencia-se das outras unidades por ter apenas um profissional de saúde (auxiliar de enfermagem) responsável para realizar o DOTS/TS no domicílio, as outras atividades atribuídas ao programa de TB e as atividades do programa de DST-AIDS. A Tabela 7.2 apresenta o número de profissionais por cada PCT nas unidades em estudo.

Tabela 7.2 - Equipe de saúde dos PTC nas unidades de saúde do município de Ribeirão Preto, julho, 2003.

\begin{tabular}{lcccc}
\hline $\begin{array}{l}\text { Categoria } \\
\text { Profissional }\end{array}$ & \multicolumn{3}{c}{ PCT } \\
\cline { 2 - 5 } & (A) & (B) & (C) & (D) \\
\hline Médico & 1 & 2 & 1 & 1 \\
Enfermeira & - & 1 & 1 & 1 \\
Auxiliar & 2 & 2 & 2 & 1 \\
\hline
\end{tabular}


Observa-se no PCT (B) uma diferença em relação aos outros programas por disponibilizar dois profissionais médicos que oferecem atendimento nos períodos de manhã e da tarde. A disponibilidade destes recursos, de certa forma, oferece para o doente e família maior acessibilidade ao programa e/ou serviço de saúde.

A organização da estratégia e/ou programa de saúde em termos de definição de critérios de inclusão do doente para a supervisão do tratamento de alguns clientes pode estar representando a atual estrutura do serviço para o atendimento ao doente e família com TB.

Nesse sentido, considera-se fundamental a identificação e a implementação de diretrizes que tenham como objetivo adotar condutas para as correções técnicas ou administrativas na operacionalização das atividades do DOTS/TS, principalmente em relação aos recursos disponibilizados para o programa. Nesse contexto é de fundamental importância que seja definido o alcance do DOTS/TS pelos PCT em termos de cobertura (inclusão de toda população de doentes ou apenas uma parte dela), para assim definir os recursos necessários, as funções de cada profissional, direcionar as atividades, disponibilizar e otimizar recursos no DOTS/TS.

Existem argumentos que todo paciente com TB deve receber DOTS/TS, pois quando este foi comparado com o Tratamento Auto-administrado (TA) o DOTS/TS não só apresenta maior número de doentes curados, como também, gera custo-beneficio (WEIS, 1997). Porém, considera-se que o DOTS/TS universal (supervisão ao 100\% dos casos TB) deve ser adotado em função da realidade e/ou necessidade de cada programa, em termos de disponibilidade de recursos, resultados de tratamento, dentre outros. É referido que o DOTS/TS não seja necessário quando o programa ou serviço de saúde apresenta alta taxa de tratamento completo (SNYDER; CHIN, 1999).

A modalidade de DOTS/TS (universal ou apenas para alguns clientes) adotada pelo serviço e/ou programa de saúde resultará em maior ou menor custo da estratégia. 
Segundo Vassall et al. (2002) dois aspectos principais determinam o custo do DOTS/TS: onde o tratamento é oferecido e o número de visitas domiciliares. Esses aspectos provavelmente influenciarão substancialmente no custo-efetividade da estratégia. Certamente o maior número de visitas domiciliares resultará em maior uso de recursos tanto materiais quanto humanos e, por conseguinte, maior custo. Porém, a freqüência desta atividade deve-se justificar em função da necessidade do programa e dos resultados obtidos em termos de regularidade, tempo e resultado do tratamento e qualidade da assistência.

Snyder e Chin (1999) questionam a prática do DOTS/TS para grupos considerados de baixo risco, quando os recursos, para o controle da TB, são fixos e as taxas de abandono são baixas. Assim, os autores também referem que o DOTS/TS universal pode não ser a melhor forma de se utilizar os recursos existentes.

Considera-se que a definição do DOTS universal ou apenas para uma parcela da população de clientes com TB deve ocorrer como resultado de uma avaliação sistematizada que tenha como objetivo principal responder os problemas e/ou necessidades identificados em cada PCT, uma vez que a realidade de cada programa é muito diversa, variando de região, de Estado, de cidades e mesmo de um distrito para outro. Indicadores operacionais tais como: regularidade do tratamento, porcentagem de abandono de tratamento, cura do doente e período de tratamento devem ser prioridade na avaliação do programa. 


\section{Aproveitamento dos recursos}

Gráfico 7. 1- Tempo de aproveitamento dos recursos do DOTS/TS no domicílio por PCT, 2003

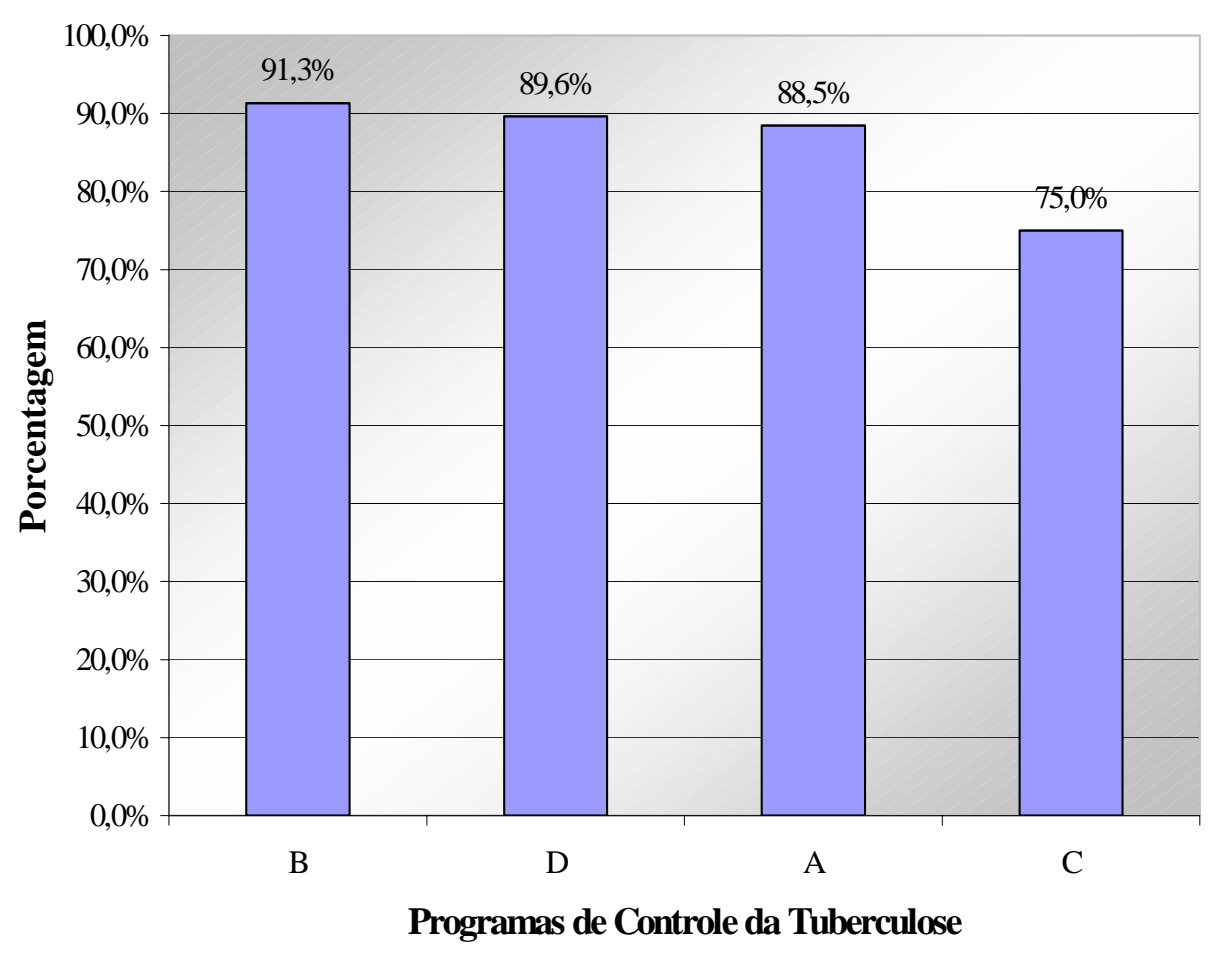

O tempo total disponível dos recursos do DOTS/TS foi 7,237 min, do qual foram gastos 6,114 min (84,5\%) na realização das visitas domiciliares. O PCT (B) apresentou maior porcentagem de aproveitamento, seguido do (D), (A) e (C). (Gráfico 7.1)

Os maiores e menores tempos de aproveitamento dos recursos pelos PCT podem estar relacionados à sobrecarga de funções do profissional de saúde, como conseqüência da disponibilidade de recursos humanos nos programas e férias de funcionários.

Em relação à sobrecarga de funções, destaca-se que o profissional da equipe de enfermagem do PCT realiza outras atividades, tanto dentro do próprio programa (pré e pós consulta do programa) como dentro do próprio serviço de saúde (pré e pós consulta do programa de Hanseníase, coleta de sangue, visita domiciliar para clínica médica, cardiologia, 
dentre outros). A equipe de enfermagem do PCT (C) assume, eventualmente, o DOTS/TS de outros PCT do município em situações de férias, licença de funcionários designados para tal função ou quando o programa não dispõe de recursos para realizar a supervisão domiciliar.

A sobrecarga de funções pode ocasionar o atraso na saída do profissional da Unidade de Saúde, trazendo como conseqüência, menor tempo para a realização de atividades do DOTS/TS no domicílio do doente de TB. Assim, pode também interferir na execução das atividades internas do serviço de saúde.

O momento da saída do profissional de saúde para a realização do DOTS/TS no domicílio implica uma série de organizações internas no serviço, de modo a redimensionar as atividades de rotina da equipe de enfermagem local que é responsável pelos programas de TB e hanseníase, dentre outras designações, de modo que não se afete o processo de trabalho na unidade de saúde (MONROE et al., 2004).

As férias de funcionários (motorista e o profissional de saúde responsável pelo DOTS/TS no domicílio) também podem influenciar no tempo de aproveitamento dos PCT. Durante o estudo, tais funcionários se encontravam de férias no PCT (A), tendo sido substituído apenas o motorista. Deste modo, a responsabilidade pela supervisão no domicílio foi assumida pelo profissional responsável das atividades do PCT (pré e pós-consulta) na unidade de saúde que exerce outras funções dentro do próprio serviço de saúde. O PCT (B) também apresentou férias do motorista, sendo este substituído por um outro funcionário cuja disponibilidade de tempo era menor.

Acredita-se que a não substituição dos profissionais devido às férias, licenças ou folgas influi diretamente no tempo de aproveitamento dos recursos para o DOTS/TS no domicílio, uma vez que a falta desses recursos reduz a equipe de saúde, trazendo como resultado a sobrecarga de funções para os profissionais de saúde da unidade que, além de assumir a responsabilidade do DOTS/TS no domicílio, devem continuar a responder pelas 
atividades atribuídas ao PCT e ao próprio serviço de saúde. Em função da complexidade dessas atividades, estas demandaram maior ou menor tempo do profissional de saúde. Essa sobrecarga de funções devido à falta de recursos, e provavelmente de organização interna e de planejamento das atividades, geralmente terá como resultado o atraso na saída do profissional para realizar o DOTS/TS no domicílio. Nesse sentido, atividades inerentes tanto ao serviço de saúde quanto ao DOTS/TS podem ser prejudicadas em termos de execução e qualidade.

O envolvimento do profissional em outras atividades inerentes ao PCT e serviço de saúde torna-se mais freqüente durante as campanhas de saúde, dificultando ainda mais a comunicação e integração da equipe de saúde do programa, prejudicando, inclusive, o planejamento da atenção ao doente com TB.

Quando comparados os PCT em relação à variável tempo disponível, encontraram-se os seguintes resultados: maior tempo PCT (C) ( $\bar{x}: 159$ min; IC: 141,7-176,3min) que no PCT (A) $(\bar{x}: 131,6$ min; IC: $123,1-140,1 \mathrm{~min})$, PCT (B) $(\bar{x}: 115,2 \mathrm{~min}$; IC: $99,6-130,8 \mathrm{~min}) \mathrm{e}$ PCT (D) ( $\bar{x}: 63,1 \mathrm{~min}$; IC: $51,0-75,2$ min) e este por sua vez apresentou o menor tempo. Por outro lado o PCT (A) e PCT (B) obtiveram tempos semelhantes (Gráfico 7.2).

Gráfico 7.2 - Distribuição dos tempos disponíveis dos recursos do DOTS/TS nos PCT segundo média e intervalo de confiança, 2003

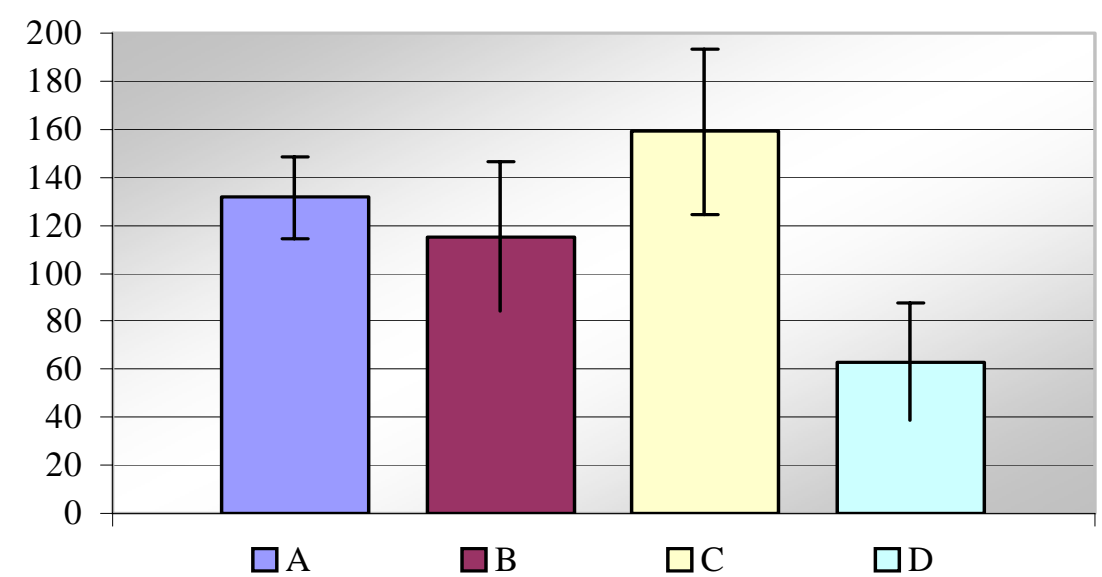


Em relação à variável tempo gasto, os resultados foram: menor tempo para PCT (D) $(\bar{x}: 56,6$; IC: 44,7-68,5) quando comparado com o PCT (C) ( $\bar{x}: 119,2 ;$ IC: $139,3-99,2)$, PCT (B) $(\bar{x}: 105,2$; IC: $89,4-121,1)$ e PCT (A) $(\bar{x}: 116,5 ;$ IC: $110,8-122,2)$, este por sua vez, apresentou tempo semelhante com o PCT (C) e o PCT (B), o qual obteve também um valor semelhante com o PCT (C).

As diferenças de tempo disponível e tempo gasto entre os PCT poderiam ser explicadas pela distribuição dos recursos humanos e materiais para o DOTS/TS no domicílio, os quais ocorrem de forma diferente para cada programa (Gráfico 7.3).

Gráfico 7. 3 - Distribuição dos tempos gastos dos recursos do DOTS/TS no domicílio por PCT segundo média e intervalo de confiança, 2003

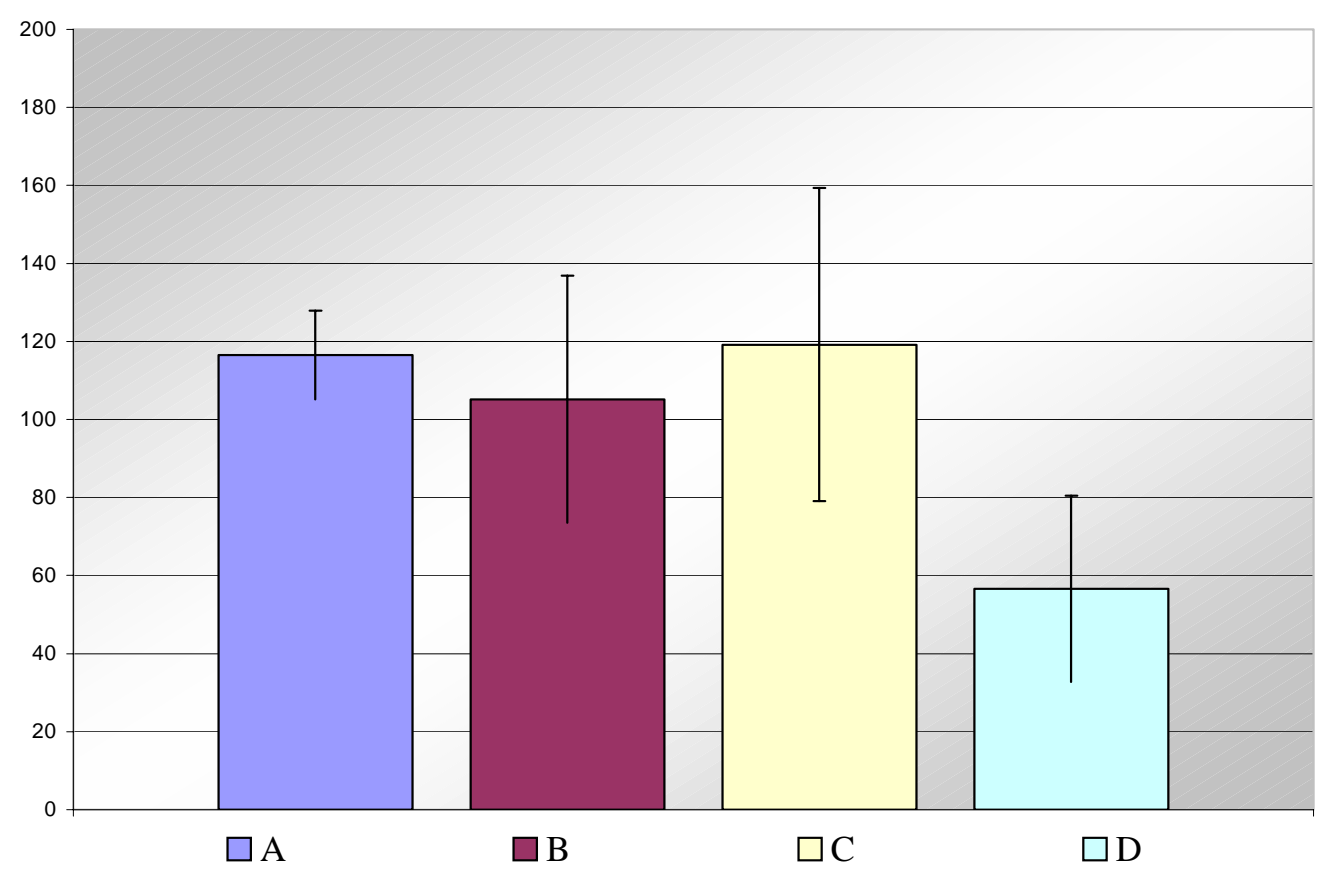

Os PCT (A) e (B) apresentaram tempo disponível semelhante. Os dois programas dispõem de recursos (viatura, motorista) para realizar especificamente as atividades do 
DOTS/TS no domicílio. O mesmo não ocorre com o PCT (C), uma vez que este divide a viatura e motorista com o PCT (D) duas vezes por semana.

Em relação ao tempo gasto, os PCT (A), (B) e (C) apresentam semelhanças provavelmente devido à maior disponibilidade dos recursos, o que não ocorre com o PCT (D), que dispõe apenas de uma hora para o uso dos recursos do programa.

O PCT (D), além do horário restrito da viatura, conta apenas com um profissional de saúde para realizar tanto as atividades do DOTS/TS no domicílio quanto as atividades internas do programa de TB e DST-AIDS. Isso difere das outras unidades que, além da disponibilidade de recursos (viatura e motorista) por um tempo maior, dispõem de dois profissionais de saúde, um para realizar o DOTS/TS no domicílio e outro responsável pela realização das atividades internas do programa.

Esta situação mostra o problema da limitação de recursos nos serviços e/ou programas de saúde. Perante a necessidade do cumprimento das atividades atribuídas a esta forma de monitoração do tratamento do doente com TB, os recursos são distribuídos aos programas em função daquilo que se tem disponibilizado, embora estes possam ser ou não suficientes para responder às demandas de cada programa. Este fato cria uma lógica de_trabalho diferente do esperado ou programado pelos profissionais de saúde em cada PCT. É evidente que nesse contexto as atividades estão orientadas apenas para a obtenção de melhores resultados de tratamento (maior cura e menos abandono).

Nesse sentido, a Observação da Ingestão Medicamentosa torna-se uma das atividades privilegiadas no DOTS/TS, uma vez que a efetivação desta atividade garante que o doente esteja tomando a medicação, fato que geralmente permite assegurar o sucesso terapêutico. Quando é realizado o DOTS/TS no domicílio, a Observação da Ingestão Medicamentosa constitui-se a finalidade principal, porém outras atividades são realizadas tais como: suporte psicológico, apoio para a continuidade do tratamento, esclarecimento de dúvidas sobre o 
tratamento, intercorrências patológicas que necessitam de apoio ou até mesmo transporte até a unidade de saúde, busca ativa de Sintomático Respiratório, entrega de incentivos, avaliação do estado de saúde, verificação da medicação pelo profissional de saúde, entrega da medicação para o doente ou familiar, coleta de materiais de clientes impossibilitados de comparecer à unidade de saúde, dentre outras.

A realização dessas atividades varia de um PCT para outro, pois ocorrem em função da demanda e organização do programa e do próprio serviço de saúde, como foi, por exemplo, observado no PCT (B), em que o profissional responsável pela supervisão domiciliar utiliza um dia da semana para coleta de sangue para exame de clientes impossibilitados de comparecer à unidade. Esta forma de organização e utilização dos recursos do DOTS/TS, também podem influenciar no tempo disponível e tempo gasto dos recursos do DOTS/TS dos PCT.

Um outro aspecto refere-se às férias de funcionários que traz como resultado a redução do número de profissionais produzindo-se uma sobrecarga de funções (problemática antes mencionada) e em conseqüência, menor tempo gasto nas atividades do DOTS/TS. Essa falta de recursos humanos exige da equipe de saúde uma rápida reorganização das atividades do DOTS/TS.

Considera-se que as férias dos funcionários devem ser contempladas como um aspecto fundamental pelos gerentes no planejamento e administração de recursos e na organização do serviço ou programa de saúde para dar continuidade às atividades de supervisão do PCT.

Quando realizado o planejamento dos recursos materiais e humanos, torna-se necessário considerar o contexto em que serão disponibilizados os recursos, com o intuito de planejar e viabilizar os recursos materiais e humanos mais próximos da realidade do serviço de modo a alcançar as metas e/ou objetivo da estratégia. 
A distribuição dos recursos diferentemente da realidade dos serviços e a não substituição de profissionais, devido às férias influenciarão na organização e execução das atividades de saúde, assim como, na qualidade da atenção prestada.

Perante os recursos limitados e à própria complexidade que envolve a prática do DOTS/TS no domicílio, exige-se dos profissionais atuantes nos PCT uma permanente superação de dificuldades de ordem pessoal (diferenças culturais) e profissional (limitação para resolver outros problemas de saúde além da TB) para efetivar as atividades de saúde. A necessidade de uma constante definição de prioridades das ações é necessário devido à falta de recursos materiais e humanos.

Nesse contexto, é necessário olhar outras formas e/ou modalidades de supervisão do tratamento de TB que possam ser utilizadas pelo PCT em concordância com a realidade do serviço e/ou programa de saúde, tais como Programa Saúde da Família e Programa de Agentes Comunitários de Saúde.

Embora os resultados tenham mostrado o PCT (D) como o programa com menor tempo para realizar o DOTS/TS no domicílio, este se apresentou como a unidade com maior aproveitamento dos recursos, o que pode representar uma clara definição das funções e/ou organização do profissional de saúde para otimizar ao máximo o tempo disponível dos recursos.

\section{Agilidade}

O número médio de visitas domiciliares por hora gasta dos recursos para o DOTS/TS foi 4,7. O PCT (A) apresentou maior número médio de visitas domiciliares seguido do PCT (D) e PCT (B) (Tabela 7.3). 
Tabela 7.3 - Número médio de visitas domiciliares por unidades de saúde segundo hora gasta dos recursos do DOTS/TS no domicílio

\begin{tabular}{cc}
\hline Unidades de Saúde & $\begin{array}{c}\mathbf{n}^{\mathbf{0}} \text { médio de VD/hora gasto dos recursos do } \\
\text { DOTS/TS no domicílio }\end{array}$ \\
\hline (A) & 5,8 \\
(B) & 4,4 \\
(C) & 4,1 \\
(D) & 4,5
\end{tabular}

O menor número de visitas domiciliares foi no PCT (C). Considera-se, que tal situação pode ser explicada pela extensa área de abrangência demandando, desta forma, maior tempo de deslocamento para a supervisão dos clientes em bairros distantes. Os outros programas estão localizados em uma área geográfica restrita. Assim, a equipe de saúde do PCT (C) realiza supervisão eventual de clientes pertencentes à área de abrangência de outros PCT do município, o que implica um tempo maior de deslocamento do profissional de saúde deste PCT para efetivar o DOTS/TS no domicílio.

Esta mesma variável (área de abrangência) pode explicar o maior número de visitas domiciliares observadas no PCT (A), uma vez que sua área de abrangência é a menor quando comparada aos outros e os domicílios localizam-se no mesmo bairro, quarteirões ou clientes residem na mesma moradia. Assim, observaram-se também, clientes que moravam no mesmo domicílio (três famílias), devido ao vínculo de parentesco ou condição de casados ou juntados.

Além da distância entre os domicílios dos clientes com TB, o resultado obtido na variável referida pode ser explicado também em função do tempo de aproveitamento dos recursos pelos PCT, porque quanto maior o tempo de aproveitamento dos recursos do DOTS/TS, maior será o tempo para que o profissional de saúde realize as visitas domiciliares. Nesse sentido, pode-se dizer que o número menor de visitas domiciliares por hora encontrado no PCT (C) pode estar atribuído também ao menor tempo de aproveitamento deste programa. 
Considera-se também que o número de clientes em DOTS/TS (cobertura) por cada PCT, bem como, a freqüência da supervisão (organização do programa) para cada doente, influenciam o número de visitas domiciliares. O programa que apresenta o maior número de clientes em DOTS/TS no domicílio, com uma freqüência de supervisão diária produz maior número de visitas.

A inclusão de clientes em Tratamento Auto-administrado (TA) no DOTS/TS ao longo do tratamento também pode influenciar no número de visitas domiciliares nos programas. Essa inclusão é o resultado de uma avaliação individual pela equipe e/ou profissional de saúde que considera os seguintes fatores: desenvolvimento de multirresistência, irregularidade no tratamento, dificuldade para tomar a medicação, falta ao retorno para consulta médica, reações adversas, dentre outros. Estes mesmos fatores também são utilizados para definir o número de vezes que o doente será supervisionado.

Quando aplicado o teste estatístico, observou-se que os resultados em relação aos PCT que obtiveram maior e menor número de visitas domiciliares estão em concordância com os dados discutidos anteriormente: maior número no PCT (A) ( $\bar{x}: 11,2$ visitas; IC: 10,6-11,7 visitas) quando comparado com o PCT (B) ( $\bar{x}:$ 7,7 visitas; IC: 6,3-9,2 visitas), PCT (C) ( $\bar{x}$ : 8,1 visitas; IC: 6,3-9,9 visitas) e o PCT (D) ( $\bar{x}:$ 4,3 visitas; 3,6-5,0 visitas), o qual apresentou menor número de visitas domiciliares durante o estudo. Os PCT (B) e (C) tiveram números semelhantes (Gráfico 7.4).

Acredita-se que a semelhança obtida nos programas (B) e (C) deve-se ao fato de que ambos apresentam as mesmas características em alguns aspectos relacionados à organização do DOTS/TS tais como: critérios de inclusão para supervisionar o tratamento do doente com TB e a definição da freqüência das supervisões (diária, uma, duas ou três vezes por semana). 
Gráfico 7. 4 - Distribuição de número de visitas domiciliares realizadas no DOTS/TS por PCT segundo média e intervalo de confiança, 2003

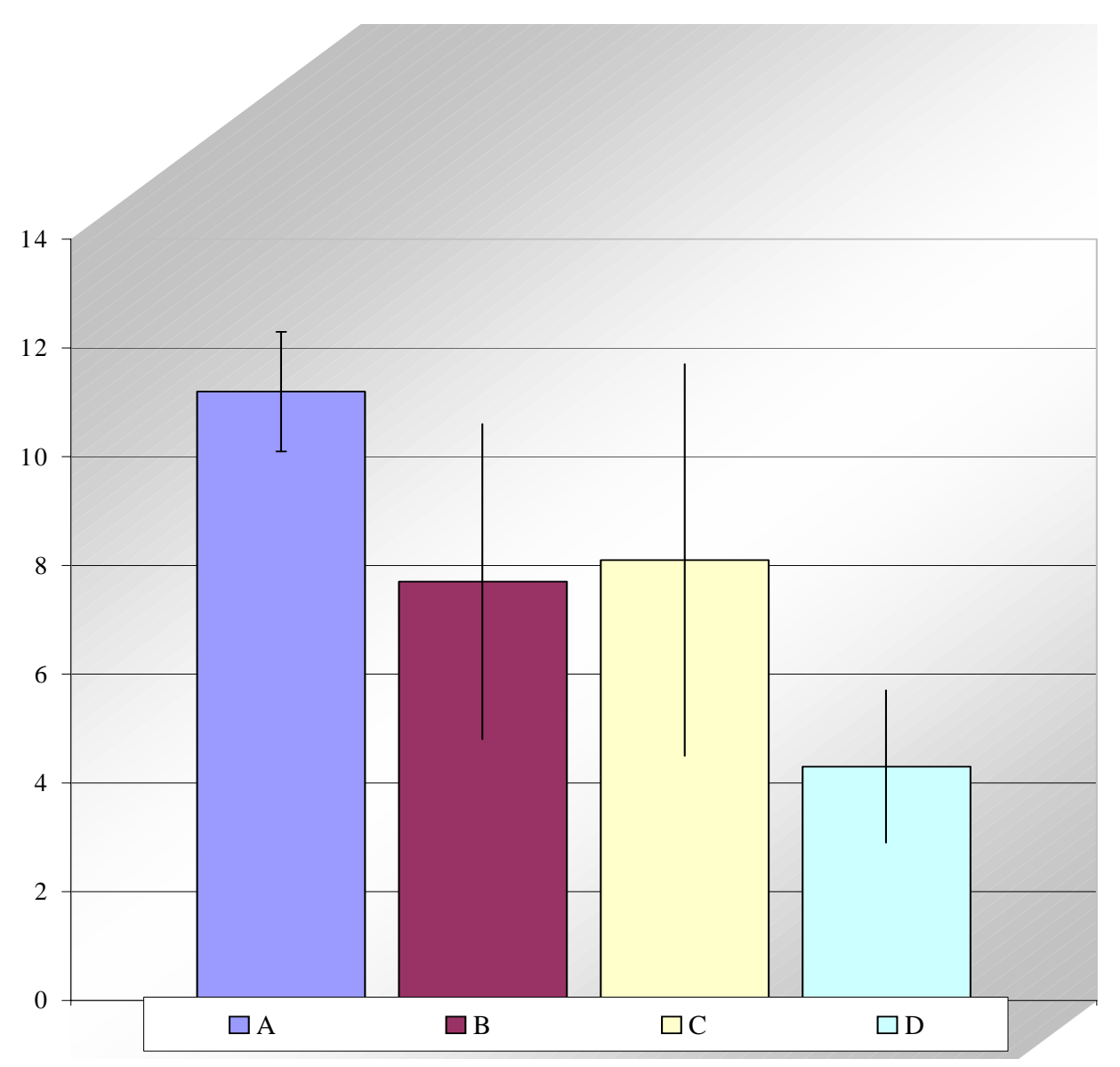

\section{Monitoração da Ingestão da Medicação}

Do total de visitas domiciliares (375) realizadas com a finalidade da Observação da Ingestão da Medicação pelos profissionais de saúde dos PCT nas unidades de saúde em estudo, 68,3\% foram efetivamente realizadas.

Quando analisadas por unidade de saúde observou-se que o PCT (A) alcançou maior porcentagem, seguida do PCT (C), PCT (D) e PCT (B) (Tabela 7.4). 
Tabela 7.4 - Porcentagem de visitas domiciliares com observação da ingestão da medicação por PCT no município de Ribeirão Preto, 2003

\begin{tabular}{cccc}
\hline Unidades de Saúde & $\mathbf{n}^{\mathbf{0}}$ de visitas para OIM & $\mathbf{n}^{\mathbf{0}}$ de visitas com OIM & $\begin{array}{c}\mathbf{n}^{\mathbf{0}} \text { de VD com OIM } / \mathbf{n}^{\mathbf{0}} \\
\text { de VD para OIM }\end{array}$ \\
\hline (A) & 146 & 113 & $77,4 \%$ \\
(B) & 62 & 34 & $54,8 \%$ \\
(C) & 103 & 68 & $66,0 \%$ \\
(D) & 64 & 41 & $64,1 \%$
\end{tabular}

As diferenças encontradas nos PCT podem estar atribuídas à forma de conduzir o DOTS/TS. Para alguns profissionais é condição necessária no DOTS/TS a Observação da Ingestão da Medicação, por considerarem esta atividade como a única forma de garantir a tomada da medicação pelo doente e favorecer a cura do mesmo. Além disso, consideram que a supervisão do tratamento deve ser realizada todos os dias, uma vez que na ausência do profissional de saúde nada garante que o doente tenha efetivamente tomado a medicação.

Snyder e Chin (1999) referem que o uso do DOTS/TS é a estratégia mais efetiva de gerenciamento de caso para assegurar o tratamento completo dos clientes com TB desde que o trabalhador de saúde observe todas as doses de medicação.

O DOTS/TS adquire maior relevância quando o doente apresenta um perfil sociocultural e econômico que o situa entre a população de maior risco de abandono e irregularidade do tratamento.

O desenvolvimento do estudo possibilitou observar que o objetivo principal do DOTS/TS é a Observação da Ingestão da Medicação. As ações de controle da tuberculose têm como foco central o tratamento do doente segundo as diretrizes das políticas de saúde na década de 90 permeado por uma relação institucionalmente intermediada, justificada pela interrupção da cadeia de transmissão. Não está prevista na rotina do PCT a implantação de um instrumento de atenção que se volte para a dimensão do autocuidado, para atenuar o sofrimento e risco de cada indivíduo doente ou comunicante (PERINI, 1998). 
Para efetivar a Observação da Ingestão da Medicação é exigido do profissional de saúde, além de habilidades técnicas, outros conhecimentos (psicologia, antropologia, dentre outros) que superam o plano terapêutico, de modo a criar condições para que se efetive tal atividade.

Já em 1980, Sbarbaro, referia que, indiscutivelmente, os esforços necessários para supervisão da administração medicamentosa pela equipe de saúde ao paciente parece ser um simples conceito a compreender, mas não é, ou seja, a realização desta atividade é complexa.

Quando o DOTS/TS é concebido de um modo mais amplo, é provável que o critério de Observação da Ingestão da Medicação apenas seja mais uma atividade dentre outras no DOTS/TS. Nesse sentido, a supervisão do tratamento adquire uma outra dimensão que valoriza o monitoramento do tratamento da medicação não apenas em função da Observação da Ingestão da Medicação pelo profissional de saúde, mas também, em função de outras formas ou modalidades de supervisão incorporadas pela equipe ou profissional de saúde, tais como: as visitas domiciliares para entregar e conferir a medicação. Uma das estratégias utilizadas pelo profissional de saúde para verificar a regularidade do tratamento pelo doente é a contagem das embalagens vazias das medicações que foram ingeridas, as quais devem estar em concordância em termo de quantidade e tempo de tratamento. Uma outra modalidade de supervisão inclui a entrega do medicamento para o doente por um determinado período geralmente não maior de uma semana.

Estas outras modalidades adotadas pela equipe ocorrem por diversos fatores: aumento da cobertura, disponibilidade de recursos humanos e materiais, adesão do doente e família manifestada em atitudes de co-responsabilidade no tratamento, reinserção do doente no mercado de trabalho e viagem, dentre outros. 
Outras formas de supervisão são significativas para alguns clientes, porque possibilita que estes retornem às suas atividades laborais sem ficarem na dependência da disponibilidade de horário de visita do profissional de saúde.

O estudo realizado por Vendramini (2001), sobre o DOTS/TS na percepção do doente mostra que este apresentou fortalezas e debilidades. Uma debilidade foi a dependência do horário para a tomada da medicação, pois os clientes manifestaram a necessidade de inserção no mercado de trabalho, impossibilitando a permanência no domicílio no período da manhã.

Fatores sociais e culturais (cliente sem local fixo de moradia, impossibilitado de deglutir os comprimidos por estar embriagado) também podem influenciar na efetivação da Observação da Ingestão Medicamentosa.

A falta do cumprimento da responsabilidade assumida pelo doente (comunicar ao serviço de saúde quando não for possível aguardar a visita do profissional) ao iniciar o DOTS/TS, muitas vezes resulta no deslocamento do profissional até o domicílio sem sucesso devido a ausência do doente.

A efetivação da Observação da Ingestão da Medicação traz à tona a necessidade de repensar um aspecto que adquire relevância na assistência ao doente com TB de forma a alcançar o sucesso no tratamento. Este aspecto está relacionado à forma de abordar o doente desde o início (visita de caso novo) e durante o processo de tratamento (visita domiciliar de supervisão) de forma a favorecer a adesão e, deste modo, possibilitar a valorização do tratamento pelo doente e família garantindo o cumprimento da terapêutica. As atividades de supervisão ocorrem a partir de um constante processo de interação entre o profissional de saúde e o doente e família em que o diálogo é geralmente árduo e penoso devido, muitas vezes, ao contexto social e cultural específico da família que condiciona e delimita as possibilidades de cuidados com a saúde. Nesse sentido, outros conhecimentos (antropologia, 
sociologia, psicologia dentre outros) além das habilidades técnicas do agente de saúde supervisor do tratamento no domicílio tornam-se indispensáveis.

A adesão é um elemento chave no tratamento do doente. O processo de adesão ao tratamento implica a participação do doente no desenvolvimento do auto-cuidado de TB criando condições para o profissional de saúde realizar outras atividades de saúde que complementem o cuidado no domicílio, com o intuito de fortalecer o estado de saúde do doente e família, assim como sua inserção social.

O doente com TB geralmente apresenta outros problemas de saúde além da doença e até mesmo problemas de origem social, emocional e econômico. Em função dessa realidade, o processo de atenção ao doente necessita incorporar estratégias complementares que viabilizem uma assistência sistematizada que possibilite o seguimento do doente por meio do acompanhamento de um profissional de saúde que coordene a assistência prestada ao doente e família em uma perspectiva mais integral complementando a observação da Ingestão Medicamentosa (atividade priorizada no DOTS/TS).

\section{Tempo gasto por Visita Domiciliar}

Em média, o tempo por visita domiciliar nos PCT em relação ao tempo médio disponível dos recursos do DOTS/TS foi de 14,8 minutos. O tempo médio gasto foi de 12,7 minutos., apresentando-se uma diferença em ambos os tempos de 2,1 minutos. (Tabela 7.5).

Tabela 7.5 - Tempo médio disponível e gasto por visita domiciliar no DOTS/TS por PCT no município de Ribeirão Preto, 2003

\begin{tabular}{ccc}
\hline Unidades de Saúde & $\begin{array}{c}\text { Tempo médio disponível dos } \\
\text { recursos do DOTS/TS/n } \\
\text { de VD }\end{array}$ & $\begin{array}{c}\text { Tempo médio gasto dos recursos } \\
\text { do DOTS/TS/n }\end{array}$ \\
\hline (A) & 11,7 & 10,4 \\
(B) & 14,4 & 13,7 \\
(C) & 19,6 & 14,7 \\
(D) & 14,7 & 13,2 \\
\hline
\end{tabular}


Gráfico 7.5 - Tempo mér
DOTS/T

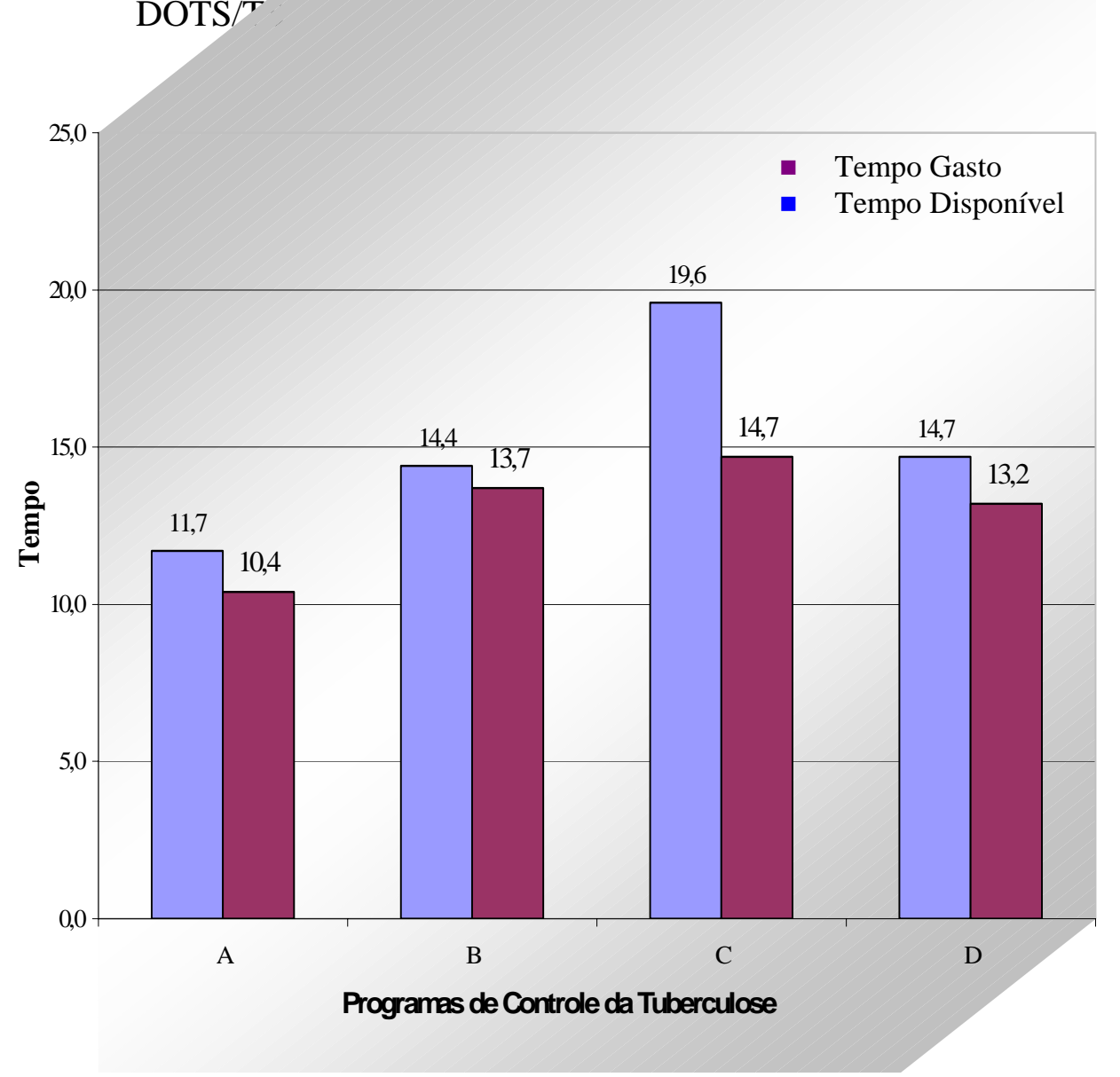

O tempo médio por visita domiciliar em relação ao tempo médio disponível e tempo médio gasto apresentou-se de forma diferenciada em cada um dos PCT, sendo que, o PCT (C) apresentou o maior tempo em relação aos outros programas. Observou-se o menor tempo no PCT (A) (Gráfico 7.5).

Acredita-se que o maior tempo gasto (14,7 minutos) por visita domiciliar do PCT (C) se deu em função do maior tempo disponível deste programa. Este PCT teve disponível 19,6 minutos, em média, para ser gasto na visita domiciliar. Porém, utilizou apenas 14,7 minutos, apresentando uma diferença de 4,9 minutos. Esse resultado pode estar atribuído ao tempo de aproveitamento dos recursos que foi o menor (75\%) quando comparado aos outros PCT. 
O menor tempo gasto por visita domiciliar observado no PCT (A) pode ser explicado pelo menor tempo de aproveitamento (88,5\%) dos recursos do PCT em relação ao PCT (B) (91,3\%) е PCT (D) $(89,6 \%)$.

Na realização das visitas domiciliares, o tempo disponível dos recursos humanos e materiais é um fator importante, tendo em vista que o impacto de algumas ações de saúde dependem do tempo em que estas são operadas. O maior tempo pode possibilitar ao profissional de saúde melhores condições para planejamento e desenvolvimento de atividades no DOTS/TS para assegurar a adesão do doente.

Portanto, o tempo gasto por visita domiciliar para a supervisão de tratamento nos PCT é influenciado tanto pelo tempo disponível quanto pelo tempo de aproveitamento dos recursos.

O planejamento das atividades de supervisão precisa considerar o número de clientes acompanhados no DOTS/TS e a freqüência da supervisão para dimensionar o tempo disponível para cada visita.

O tempo gasto obtido por visita domiciliar inclui o tempo de deslocamento do profissional até o domicílio do doente e tempo utilizado na visita.

A disponibilidade de tempo na execução das visitas domiciliares no DOTS/TS é também essencial devido à necessidade de resolver outros problemas de saúde associados (diabetes, hipertensão, dentre outras), assim como, necessidades sociais presentes no contexto familiar do doente com TB. O profissional de saúde muitas vezes é percebido pelo doente como um recurso fundamental para dar resposta imediata a seus problemas e/ou necessidades considerados como prioridade. Deste modo, a realização de outras atividades são necessárias não apenas para favorecer a adesão, mas também, para promover uma assistência integral ao doente e família. Estas outras atividades, geralmente incluem agendamento para consulta médica, encaminhamentos, transporte, coordenações com o serviço de saúde e pactuações 
entre o profissional de saúde e o doente e família para a continuidade das atividades de assistência e vigilância após a conclusão do tratamento da TB. Estas atividades complementam o processo de atenção ao doente e necessitam de disponibilidade de recursos (viatura e motorista) e previsão de atividades considerando o número de clientes a serem supervisionados.

Considera-se que é condição necessária a disponibilidade de um tempo maior para a realização da visita domiciliar no DOTS/TS com o intuito de prestar uma assistência integral e de qualidade, que envolve a interação entre as pessoas (doente/família e profissionais de saúde) geralmente com características sócio-culturais e econômicas diferentes. A identificação de situações de risco do não cumprimento da terapêutica e de necessidades de um apoio profissional que transcende uma condição patológica momentânea é de fundamental importância na assistência ao paciente e família (PERINI, 1998).

\section{II. “Ocorrências” durante o DOTS/TS no Domicílio}

Considerando os objetivos do estudo, as ocorrências relacionadas ao serviço de saúde foram das mais diversas. No PCT (A) observou-se que um dos eventos mais freqüente durante a realização do DOTS/TS estava relacionado à procura e entrega de materiais na UBDS e Centro de Referência (11). Outros eventos foram: problema com a viatura (3), supervisor assumindo atividades internas no serviço de saúde (1) e outros (3).

No PCT (B) as ocorrências estavam relacionadas à procura de endereço errado/ou confuso (4).

No PCT (C) observou-se ocorrências, tais como: Veículo impedindo a saída da viatura (1), desencontro entre o profissional de saúde e motorista (1) supervisor assumindo atividades internas no serviço de saúde (1), folga do profissional de saúde responsável pelo 
DOTS/TS no domicílio (1), esquecimento do material de supervisão (1), ausência do funcionário no serviço (1) e outros (5).

No PCT (D), as ocorrências que mais se observou foram: supervisor assumindo atividades internas no serviço de saúde (3) folga do profissional de saúde responsável pelo DOTS/TS no domicílio (1) e outros (2).

Quanto às ocorrências relacionadas ao doente família e comunidade, os eventos no PCT (A), foram: doente não estava no domicílio (11); horário estabelecido pelo doente para a ingestão da medicação (12), dificuldade para engolir a medicação (2) tomada da medicação antes do profissional de saúde chegar (1); reações adversas à medicação (1); doente dormindo (1).

No PCT (B), doente não estava no domicílio (12); tomou a medicação antes do profissional de saúde chegar (9); família problemática (3); endereço inexistente (2) mudou de endereço (2); doente viajou (1) e internação do doente (1).

No PCT (C), doente não estava no domicílio (22); tomada da medicação antes do profissional de saúde chegar (9); horário preestabelecido para a ingestão da medicação (3); internação (1); endereço inexistente (1) doente dormindo (1); outros (2).

No PCT (D), doente não estava no domicílio (22).

Observa-se que a ocorrência doente não estava no domicílio foi a mais freqüente em todos os PCT. Esta situação pode acontecer devido às necessidades individuais e sociais dos clientes relacionadas a compromisso familiar, busca de emprego, dentre outros, e também por fatores relacionados ao serviço de saúde como atraso do profissional.

O tratamento de TB caracteriza-se por ter a duração mínima de seis meses e possibilitar uma permanente e prolongada interface entre doente e equipe de saúde. Nesse sentido, ocorrências relacionadas ao serviço de saúde ou doente/família podem acontecer durante este processo, influenciando desta forma no desempenho do DOTS/TS. 
Quando analisadas as ocorrências relacionadas ao serviço de saúde, pode-se perceber que estas influenciam na otimização dos recursos do DOTS/TS, uma vez que tais eventos, de alguma forma, diminuem o tempo disponível dos recursos para a realização da supervisão no domicílio.

Tanto as ocorrências relacionadas ao serviço de saúde quanto as relacionadas ao doente e família mostram a necessidade de uma contínua avaliação e planejamento sistematizado das atividades no DOTS/TS pela equipe de saúde com a finalidade de detectar as dificuldades e/ou problemas e assim elencar os eventos que devem ser monitorados na supervisão domiciliar de modo a prevenir a ocorrências dos mesmos e deste modo efetivar as atividades e otimizar os recursos no DOTS/TS. 


\section{CONCLUSÕES}

Os indicadores construídos nesse estudo possibilitam avaliar o desempenho dos serviços de saúde na execução do DOTS/TS no domicílio e como as equipes do PCT têm utilizado os recursos materiais e humanos em diferentes áreas de abrangência do município de Ribeirão Preto.

O planejamento de recursos, a organização do trabalho pela equipe de saúde, a definição de funções e a sistematização das ações no processo de tratamento do doente de TB podem influenciar no melhor aproveitamento dos recursos e deste modo, melhor desempenho do DOTS/TS no nível municipal.

$>$ A execução do DOTS/TS, no que tange à Observação da Ingestão Medicamentosa no domicílio do doente pela equipe de saúde depende do planejamento de recursos humanos, materiais (viatura) e preparo da equipe do serviço de saúde.

O PCT que responde pelo tratamento de doentes em áreas de maior abrangência apresentou menor número de visitas domiciliares influenciando, deste modo, na agilidade do desempenho do PCT.

Fatores sociais, culturais e econômicos (inserção no mercado de trabalho, viagem, endereço inexistentes, dentre outros) assim como, a forma de abordagem na supervisão do tratamento do doente de TB podem influenciar na Observação da Ingestão da Medicação. 
> A disponibilidade de tempo dos recursos (viatura, motorista e profissional de saúde) na execução das visitas domiciliares no DOTS/TS é essencial para oferecer uma assistência integral que assegura o acesso aos diferentes níveis e serviços do sistema de saúde e que atenda às necessidades sociais, culturais e econômicas do doente de TB/família.

O planejamento sistematizado e contínuo do processo de assistência de cada doente/família com adequado sistema de registro sobre os cuidados prestados pela equipe do PCT durante a supervisão do tratamento no domicílio é necessário para a avaliação de cada caso visando assegurar a continuidade da assistência. 


\section{CONSIDERAÇÕES FINAIS}

Os resultados do estudo mostraram como a disponibilidade dos recursos humanos e materiais no serviço de saúde podem influenciar no desempenho dos PCT que utilizam o DOTS/TS no domicílio, em termos de otimização dos recursos e efetivação das atividades de acompanhamento do tratamento do doente. Sendo reconhecida a utilidade desta forma de acompanhamento do tratamento do doente de TB para alcançar maior impacto no perfil epidemiológico da doença e perante os recursos humanos e materiais insuficientes nos serviços de saúde, é necessário repensar outras modalidades de supervisão e/ou integrar as atividades de controle e tratamento da doença a outras estratégias de intervenção que resultem no uso racional dos recursos, assim como, na melhoria da assistência e sucesso do tratamento.

Nesse sentido é possível avançar na construção de um trabalho articulado entre equipe do PCT e as equipes do PSF/PACS por meio do planejamento, gestão e assistência, destacando-se a capacitação de pessoal e a definição de competências, no sentido de oferecer uma assistência integral contínua e resolutiva permeada pelo respeito da equipe de saúde às diferenças culturais, sociais e econômicas do doente e família.

O desenvolvimento do DOTS/TS no domicílio em Ribeirão Preto segue os princípios da regionalização em distritos sanitários sendo que o doente de TB recebe o tratamento em ambulatórios de referência segundo área de abrangência; porém é importante destacar que existe flexibilidade para o acompanhamento do doente pertencente a outras áreas. Esta realidade exige uma permanente comunicação entre as equipes do PCT como também entre estas com outros serviços de saúde (Unidades Básicas e hospitais) de modo a articular as ações de saúde em todos os níveis de atenção e prestação de serviços.

As atividades de supervisão ainda têm como foco central a atenção medicalizada, porém, cabe destacar que durante o desenvolvimento desta ação é possível realizar outras 
intervenções que complementem o cuidado, tais como: ações de vigilância epidemiológica (busca de contatos e sintomáticos respiratórios), atividades de suporte social, dentre outras.

O desenvolvimento dessas atividades representa um desafio permanente para a equipe de saúde perante a complexidade da execução do DOTS/TS no domicílio devido às dificuldades de recursos nos serviços de saúde, diferenças culturais, sociais e econômicas tanto dos profissionais como dos clientes.

O DOTS/TS foi adotado para favorecer a adesão do doente ao tratamento. Isso somente é possível a partir do estabelecimento de vínculo entre o profissional de saúde e o doente/família possibilitando maior co-responsabilização no processo terapêutico e promoção do autocuidado, criando condições para o profissional de saúde realizar outras atividades de saúde que complementem o cuidado no domicílio.

A prática do DOTS/TS no domicílio exige capacitação e supervisão permanente dos profissionais envolvidos na atenção ao doente e família com TB; apropriação de novos conhecimentos para o planejamento e execução das ações de saúde e articulação da assistência entre o serviço e o doente e família.

A disponibilidade de recursos pode condicionar e delimitar as possibilidades de cuidados em relação à assistência à saúde e locais de prestação de serviços. Assim, cria-se uma lógica de trabalho diferente do programado pelos profissionais de saúde e exige uma rápida e contínua reorganização das atividades do DOTS/TS.

Considera-se importante estimular o desenvolvimento de estudos de avaliação do desempenho dos serviços de saúde que executam o DOTS/TS no domicílio por meio de indicadores para instrumentalizar as atividades de saúde no nível gerencial da atenção e no nível operacional/execução da assistência.

No nível gerencial é necessário rever a forma de planejamento das ações de saúde, dos recursos humanos e materiais necessários para realização de atividades do DOTS/TS no 
domicílio com a finalidade de atender à realidade social, com suas limitações e dificuldades específicas.

No nível operacional é necessário avaliar a cobertura, o aproveitamento dos recursos, o tempo gasto por supervisão, o tipo de atividades realizadas nas visitas de supervisão com a finalidade de visualizar outras modalidades ou locais de supervisão em concordância com as especificidades de cada PCT.

Finalmente, considera-se que o desempenho do DOTS/TS no domicílio precisa ser pensado em relação a dois aspectos: o local de prestação de serviço incluindo a organização interna da equipe responsável pela supervisão do tratamento; gerência do serviço que organiza os recursos para determinar o local (domicílio ou unidade) e o responsável pela supervisão ou por uma terceira pessoa que está desenvolvendo essas ações.

Cabe às unidades de saúde atribuir responsabilidades específicas para os profissionais supervisores que realizam o DOTS/TS no domicílio. Em relação ao tratamento é necessário uma apropriação de saberes e conhecimentos a serem utilizados no processo de assistência e articulação com outros serviços ou setores (social, educação, dentre outros).

O DOTS exige o planejamento e gerenciamento de recursos humanos e materiais para viabilizar o acompanhamento do doente. Na prática nem sempre os programas têm um profissional de saúde na equipe que se volte para o planejamento e gerenciamento dos recursos dos programas; geralmente isso é realizado de uma maneira rotineira, voltado às necessidades emergenciais, sem que haja um planejamento individual para cada caso, uma vez que o processo de adoecimento não é apenas biológico, mas uma história de vida do doente e família. 


\section{REFERÊNCIAS BIBLIOGRÁFICAS}

AGÊNCIA BRASIL. No Dia Mundial de Luta contra a Tuberculose, Brasil tem pouco a comemorar. Disponível em: http://www.tropinet.org/adCmsDocumentoShow.aspx?documento=349\&Area=0>. Acesso em: 05 abril. 2004.

BRASIL. Ministério da Saúde. Fundação Nacional de Saúde. Centro Nacional de Epidemiologia. Coordenação Nacional de Pneumologia Sanitária. Controle da tuberculose : diretrizes do plano de ação emergencial para municípios prioritários. Brasília, 1997.

BRASIL. Ministério da Saúde. Secretaria de Vigilância em Saúde. Departamento de Vigilância Epidemiológica. Coordenação Geral de Doenças Endêmicas. Área Técnica de Pneumologia Sanitária. Programa Nacional de Controle da Tuberculose. Brasilia, 2004.

DONABEDIAN, A. The definition of quality and approaches to its assessment. Michigan: Ann Arbor/Health Administration Press, 1980.

FAVARO, P.; FERRIS, L. Increasing the relevancy and usefulness of programme evaluation: a comprehensive evaluation. Hygie, Paris, v. 7, p. 28-32, 1988.

FUJIWARA, P. I. et al. Directly observed therapy in New York city. History, implementation, results and challenges. Clin. Chest Med., Philadelphia, v. 18, n. 1, p. 13548, 1997.

GAZETTA, C. E. Aspectos epidemiológicos da tuberculose em São José do Rio Preto-SP a partir das notificações em um hospital-escola (1993-1998). 1999. Tese (Doutorado em Saúde Pública) - Escola de Enfermagem de Ribeirão Preto/USP, 1999.

HINO, P. Distribuição espacial dos casos de tuberculose no município de Ribeirão Preto, nos anos de 1998 a 2002. 2004. 97 f. Dissertação (Mestrado em Saúde Pública) - Escola de Enfermagem de Ribeirão Preto/USP, 2004.

MONROE, A. A.; VILLA, T. C. S.; HINO, P.; VENDRAMINI, S. H. F.; MUNIZ, J. N. Aspectos que influenciam a adesão do paciente e família ao tratamento de tuberculose. In: CONGRESSO PAULISTA DE SAÚDE PÚBLICA, 7, Santos, 2001. Anais. Santos (SP): Associação Paulista de Saúde Pública, 2001. 
MONROE, A. A.; CARDOZO-GONZALES, R. I.; SASSAKI, C. M.; VILLA, T. C. S. Gerenciamento de caso ao doente/família com tuberculose: uma estratégia de sistematização do cuidado no domicílio. Jornal Brasileiro de Pneumologia, v. 31, n. 1, p. 91, 92, 2005.

MORRONE, N.; SOLHA, M. S. S.; CRUVINEL, M. C.; MORRONE JR., N.; FREIRE, J. A. S.; BARBOSA, Z. L. M. Tuberculose: tratamento supervisionado "vs." tratamento autoadministrado. Jornal de Pneumologia, v. 25, n. 4, p. 198-206, 1999.

MUNIZ, J. N. O Tratamento supervisionado no controle da tuberculose em Ribeirão Preto: uma intervenção de que tipo?. 1999. f. Dissertação (Mestrado em Saúde Pública) Escola de Enfermagem de Ribeirão Preto/USP, 1999.

MUNIZ, J. N.; VILLA, T. C. S. Tratamento supervisionado no controle da tuberculose em Ribeirão Preto: novo modo de agir em saúde. Boletim de Pneumologia Sanitária, Rio de Janeiro, v. 7, n. 1, p. 33-42, 1999.

MUNIZ, J. N.; VILLA, T. C. S. O impacto epidemiológico do tratamento supervisionado no controle da tuberculose em Ribeirão Preto (1998-2000). Boletim de Pneumologia Sanitária, Rio de Janeiro, v.10, n. 1, p. 49-54, 2002.

MUNIZ, J. N.; VILLA, T. C. S.; FERREIRA, H. Impacto Epidemiológico do Tratamento Supervisionado no Controle da Tuberculose em Ribeirão Preto. In: CONGRESSO BRASILEIRO DE EPIDEMIOLOGIA, 5. - EPI 2002; 2002; Curitiba (PR). Anais. Curitiba: colocar a instituição responsável pelo evento, 2002. p. 259.

MUNIZ, J. N. O Programa de Agentes Comunitários de Saúde na Identificação de Sintomáticos Respiratórios no Controle da Tuberculose em Ribeirão Preto-SP: um desafio para a atenção primária à saúde. 2004. 148 f. Tese (Doutorado em Saúde Pública) Escola de Enfermagem de Ribeirão Preto/USP, 2004.

NOVAES, M. D. H. Avaliação de programas, serviços e tecnologias em saúde. Rev. Saúde Publica, São Paulo, v. 34, n. 5, p. 547-549, 2000.

PERINI, E. O abandono do tratamento da tuberculose: transgredindo regras, banalizando conceitos.1998. 218 f. Tese (Doutorado em Ciência Animal) - Escola de Veterinária/UMG, 1998.

ORGANIZACIÓN PANAMERICA DE LA SALUD. Programas nacionales de control de TB. Oficina Regional de la OMS. OPS/HCP/HCT176/00.

México, 2000. 
ORGANIZACIÓN PANAMERICANA DE SALUD. Oficina Sanitária Panamericana, Oficina Regional de la Organización Mundial de la Salud, v. 5, n. 1, febrero 2002. Washington DC, 2002. 200037. OPS/OMS/HCT/TUB/2002.

ORGANIZACIÓN PANAMERICA DE LA SALUD. Tuberculosis. Hoja Informativa 2004, Americas. Disponível em: http:/www.paho.org/Spanish/AD/DPC/CD/tb-fact-sheet2004.pdf. Acesso em: 01 abr. 2005

RUFFINO NETTO A. Impacto da reforma do setor saúde sobre os serviços de tuberculose no Brasil. Boletim de Pneumologia Sanitária, Rio de Janeiro, v. 7, n. 1., p. 7-18, 1999.

RUFFINO NETTO, A. Programa de Controle da Tuberculose no Brasil: situação atual e novas perspectivas. IESUS, v. 10, n. 3, p.129-38, 2001.

RUFFINO NETTO A. Tuberculose: a calamidade negligenciada. Rev. Sociedade Brasileira de Medicina Tropical, v. 1, n. 35, p. 51-8, 2002.

SANTOS, C. B.; HINO, P.; MUNIZ, J.; VILLA, T. C. S. Tuberculose: indicadores epidemiológicos e de impacto da doença para Ribeirão Preto no período 1990 a 2000. Boletim Pneumologia Sanitária, Rio de Janeiro, v. 10, n. 1, p. 31-40, 2002.

SASSAKI, C. M.; ARCÊNCIO, R. A.; COSTA JÙNIOR, N. L.; PALHA, P. F.; CARDOZOGONZALES, R. I.; VILLA, T. C. S. Tempo de Tratamento de pacientes inscritos no programa de controle da tuberculose. Ribeirão Preto-SP (1998-1999). Boletim de Pneumologia Sanitária, Rio de Janeiro, v. 10, n. 2., p. 27-34, 2002.

SASSAKI, C. M. Tempo de Tratamento da Tuberculose de pacientes inscritos em um serviço de saúde do município de Ribeirão Preto - SP (1998-1999). 2003. 96 f. Dissertação (Mestrado em Saúde Pública) - Escola de Enfermagem de Ribeirão Preto/USP, 2003.

SBARBARO, J. A. Public Health aspects of tuberculosis: supervision of therapy. Clinics in Chest Medicine, v. 1, n. 2, p. 253-63, 1980.

SNYDER, D. C.; CHIN, D. P. Cost-effectiveness analysis of directly observed therapy for patients with tuberculosis at low risk for treatment default. Am. J. Resp. Crit. Care Med., v. 160, p. 582-6, 1999.

SOCIEDADE BRASILEIRA DE PNEUMOLOGIA E TISIOLOGIA. II Diretrizes Brasileiras para Tuberculose 2004. Jornal Brasileiro de Pneumologia, v. 30, p. S1-S86, junho. 2004. 
STARFIELD, B. Atenção primária: equilibrio entre necessidades de saúde, serviços e tecnologia. Brasília: Ministério da Saúde/Unesco, 2002. 725 p.

TANAKA, Y.O.; MELO, C. Avaliação de programas de saúde do adolescente: um modo de fazer. São Paulo: EDUSP, 2001. p. 83.

VASSALL, A.; BAGDADI, S.; BASHOUR, H.; ZAHER, H.; MAAREN, P. V. Costeffectiveness of different treatment strategies for tuberculosis in Egypt and Syria. Int. J. Tuberc. Lung Dis. V. 6, n. 12, p. 1083 - 1090, 2002

VENDRAMINI, S. H. F. O tratamento supervisionado no controle da tuberculose em Ribeirão Preto sob a percepção do doente. 2001. Dissertação (Mestrado em Saúde Pública) - Escola de Enfermagem de Ribeirão Preto/USP, 2001.

VENDRAMINI, S. H.; VILLA, T. C. S.; PALHA ,P. F.; MONROE, A. A. Tratamento supervisionado no controle da tuberculose em uma unidade de saúde de Ribeirão Preto: a percepção do doente. Boletim de Pneumologia Sanitária, Rio de Janeiro, v. 10, n. 1, p. 5-12, 2002.

VILLA, T. C. S.; PALHA, P. F.; MUNIZ, J. N.; CARDOZO-GONZALES, R. I.; PINTO NETTO, J. M.; ASSIS, M. M. A. A vigilância epidemiológica e a perspectiva de trabalho no território - Secretaria Municipal de Saúde - Ribeirão Preto. Rev. Latino-Am. Enfermagem, v. 10, n. 1, p. 21-7, 2002.

WATANABE, A.; RUFFINO NETTO, A. Aspectos epidemiológicos da co-infecção Tuberculose/HIV- Ribeirão Preto-SP. Rev. Medicina, Ribeirão Preto, v. 28, p. 856-65, 1995.

WEIS, S. E. Universal directly observed therapy: a treatment stratregy for tuberculosis. Clin. Chest Med., v. 18, p.155-63, 1997.

WORKSHOP-REDE BRASILEIRA DE PESQUISA EM TUBERCULOSE, 1., 2002, Rio de Janeiro. Anais. Rio de Janeiro: UFRJ, 2002. 116 p.

WORLD HEALTH ORGANIZATION. Framework for effective tuberculosis control. WHO/TB/94.179, 1994. Geneva: WHO, 1994.

WORLD HEALTH ORGANIZATION Ad-hoc Committee on the tuberculosis epidemic. WHO/TB/98.245, 1998. Geneva: WHO, 1998. 
WORLD HEALTH ORGANIZATION. WHAT IS DOSTS?. A guide to understanding the WHO-recommended TB control strategy known as DOTS. WHO/CDS/CPC/TB/99.270. Washington: WHO, 1999.

WORLD HEALTH ORGANIZATION. Report of the ministerial conference on TB a sustainable development. WHO/CDS/STB/2000.6. Amsterdam, WHO, .2000.

WORLD HEALTH ORGANIZATION- An Expanded DOTS Framework for Effective Tuberculosis Control. Stop TB Communicable Diseases. WHO Report 2002. WHO/CDS/TB/2002.297. Geneva: WHO, 2002a.

WORLD HEALTH ORGANIZATION. Global Tuberculosis Control: Surveillance, Planning, Financing. WHO Report, WHO/CDS/TB/2002.295. Geneva: WHO, 2002b.

WORLD HEALTH ORGANIZATION. Tuberculosis Control: Surveillance, Planning, Financing. WHO Report 2003. WHO/TB/2003.316. Geneva, Swtzerland: WHO, 2003.

WORLD HEALTH ORGANIZATION. Disponível em: $<$ http://www.who.int/tb/publications/global_report/2004/en/Brazil.pdf $>$. Acesso em: 05 abr. 2004. 


\section{ANEXOS}

ANEXO I

FORMULÁRIO INDIVIDUAL DO PACIENTE

Nome:

$\mathrm{N}^{\circ}$ de prontuário

$\mathrm{N}^{0}$ de paciente:

\section{Dados Sócio-demográficos}

$\begin{array}{lll}\text { Sexo: } & \text { 1. Masculino 2. Feminino }\end{array}$

Idade:

Escolaridade:

0 -S/escolaridade/analfabeto. 1-S/escolaridade/alfabetizado. 2-Ensino Fundamental incompleto.

3- Ensino Fundamental completo. 4-Ensino Médio incompleto. 5-Ensino Médio completo. 8Ensino Superior incompleto. 9 -Ensino Superior completo. 10-Ignorado.

Ocupação:

0-Nível superior. 1- Nível médio. 2-Braçal

3-Vive de renda. 4- Auxílio doença. 5-Aposentado.

6-Estudante. 7- Do lar. 8- Desempregado. 9-Outros. 10- Ignorado.

Dados referente ao diagnóstico, condição e esquema de tratamento e doenças associadas Forma clínica:

1-Pulmonar. 2-Extra-pulmonar

Condição de tratamento

1-Tratamento inicial (caso novo). 2-Retratamento após abandono

3-Retratamentode recidiva. 4-Retratamento nos casos de falência

Esquema de Tratamento

1-I $\quad$ 2-IR $\quad 3$-II $\quad 4$-III $\quad$ 5-Esquema Especial 10 -Ignorado

Doenças Associadas

AIDS

1-Sim 2-Não 10-Ignorado

Início do TS

Início do tratamento:

2.Início do TS:

Mês

de

tratamento: 
ANEXO II

FORMULÁRIO PARA COLETA DE DADOS

Dados relacionados à estrutura do DOTS/TS

Visitador sanitário:

Idade:

Profissão:

Tempo de trabalho no PCT-DOTS/TS:

Motorista:

Idade:

Tempo de trabalho no PCT-DOTS/TS:

Tempo programado da viatura para supervisão:

\begin{tabular}{|l|l|l|l|l|l|l|l|l|l|l|l|l|l|l|l|l|l|l|l|l|l|}
\hline $\begin{array}{c}\text { Tempo gasto na } \\
\text { supervisão por } \\
\text { dia }\end{array}$ & 1 & 2 & 3 & 4 & 5 & 6 & 7 & 8 & 9 & 10 & 11 & 12 & 13 & 14 & 15 & 16 & 17 & 18 & 19 & 20 \\
\hline Hora disponível & & & & & & & & & & & & & & & & & & & & \\
\hline Hora de início & & & & & & & & & & & & & & & & & & & & \\
\hline Hora de término & & & & & & & & & & & & & & & & & & & & \\
\hline
\end{tabular}




\section{Dados relacionados ao processo do DOTS/TS}

\section{Cobertura do DOTS/TS}

$\mathrm{N}^{\mathrm{o}}$ de pacientes com DOTS/TS:

Total de pacientes em tratamento de tuberculose

Supervisões

\begin{tabular}{|l|c|c|c|c|}
\hline Dias & $\begin{array}{c}\mathrm{n}^{0} \text { de supervisões } \\
\text { realizadas }\end{array}$ & $\begin{array}{c}\mathrm{n}^{0} \text { de supervisões } \\
\text { observando a tomada da } \\
\text { medicação }\end{array}$ & $\begin{array}{c}\text { Visita domiciliar para } \\
\text { outras atividades }\end{array}$ & Observações \\
\hline 1 & & & & \\
\hline 2 & & & & \\
\hline 3 & & & & \\
\hline 4 & & & & \\
\hline 5 & & & & \\
\hline 6 & & & & \\
\hline 7 & & & & \\
\hline 8 & & & & \\
\hline 9 & & & & \\
\hline 10 & & & & \\
\hline
\end{tabular}




\section{Ocorrências}

\section{- Relacionadas ao serviço de saúde}

\begin{tabular}{|c|c|c|c|c|c|c|c|c|c|c|c|c|c|c|c|c|c|c|c|c|c|c|}
\hline \multirow{2}{*}{$\begin{array}{c}\text { Eventos ou } \\
\text { Situações }\end{array}$} & \multicolumn{22}{|c|}{ Dias } \\
\hline & 1 & 2 & 3 & 4 & 5 & 6 & 7 & 8 & 9 & $\begin{array}{l}1 \\
0\end{array}$ & $\begin{array}{l}1 \\
1\end{array}$ & $\begin{array}{l}1 \\
2\end{array}$ & $\begin{array}{l}1 \\
3\end{array}$ & $\begin{array}{l}1 \\
4\end{array}$ & $\begin{array}{l}1 \\
5\end{array}$ & $\begin{array}{l}1 \\
6\end{array}$ & & $\vec{z}$ & & $\begin{array}{l}1 \\
9\end{array}$ & $\begin{array}{l}2 \\
0\end{array}$ & Observações \\
\hline $\begin{array}{c}\text { Funcionário faltou ao } \\
\text { trabalho }\end{array}$ & & & & & & & & & & & & & & & & & & & & & & \\
\hline $\begin{array}{l}\text { Supervisor assumindo } \\
\text { atividades internas no } \\
\text { serviço de saúde }\end{array}$ & & & & & & & & & & & & & & & & & & & & & & \\
\hline $\begin{array}{l}\text { Necessidade em } \\
\text { transportar pacientes/ } \\
\text { materiais não } \\
\text { relacionados ao TS }\end{array}$ & & & & & & & & & & & & & & & & & & & & & & \\
\hline $\begin{array}{c}\text { Viatura chegou com } \\
\text { atraso no serviço de } \\
\text { saúde } \\
\end{array}$ & & & & & & & & & & & & & & & & & & & & & & \\
\hline $\begin{array}{c}\text { Problemas com a } \\
\text { viatura (mecânicos, } \\
\text { pneu furado, falta de } \\
\text { combustível). }\end{array}$ & & & & & & & & & & & & & & & & & & & & & & \\
\hline Falta de medicação & & & & & & & & & & & & & & & & & & & & & & \\
\hline Outros & & & & & & & & & & & & & & & & & & & & & & \\
\hline
\end{tabular}




\section{- Relacionados ao paciente}

\begin{tabular}{|c|c|c|c|c|c|c|c|c|c|c|c|c|c|c|c|c|c|c|c|c|c|}
\hline \multirow{2}{*}{$\begin{array}{l}\text { Eventos ou } \\
\text { Situações }\end{array}$} & \multicolumn{21}{|c|}{ Dias } \\
\hline & 1 & 2 & 3 & 4 & 5 & 6 & 7 & 8 & 9 & 10 & 11 & 12 & 13 & 14 & 15 & 16 & 17 & 18 & 19 & 20 & Observações \\
\hline $\begin{array}{l}\text { Paciente não estava } \\
\text { no domicílio }\end{array}$ & & & & & & & & & & & & & & & & & & & & & \\
\hline $\begin{array}{c}\text { Paciente mudou de } \\
\text { endereço }\end{array}$ & & & & & & & & & & & & & & & & & & & & & \\
\hline Endereço inexistente & & & & & & & & & & & & & & & & & & & & & \\
\hline $\begin{array}{c}\text { Dificuldade para } \\
\text { engolir a medicação }\end{array}$ & & & & & & & & & & & & & & & & & & & & & \\
\hline $\begin{array}{l}\text { Nega-se a tomar a } \\
\text { medicação }\end{array}$ & & & & & & & & & & & & & & & & & & & & & \\
\hline Internação & & & & & & & & & & & & & & & & & & & & & \\
\hline $\begin{array}{l}\text { Reações adversas } \\
\text { relacionadas com 2a } \\
\text { medicação }\end{array}$ & & & & & & & & & & & & & & & & & & & & & \\
\hline $\begin{array}{l}\text { Paciente alcoolizado } \\
\text { sem condições de } \\
\text { tomar a medicação }\end{array}$ & & & & & & & & & & & & & & & & & & & & & \\
\hline $\begin{array}{c}\text { Comportamento } \\
\text { agressivo }\end{array}$ & & & & & & & & & & & & & & & & & & & & & \\
\hline $\begin{array}{l}\text { Reações adversas não } \\
\text { relacionadas ao } \\
\text { tratamento }\end{array}$ & & & & & & & & & & & & & & & & & & & & & \\
\hline $\begin{array}{l}\text { Paciente tomou } \\
\text { medicação antes do } \\
\text { profissional chegar }\end{array}$ & & & & & & & & & & & & & & & & & & & & & \\
\hline Outros & & & & & & & & & & & & & & & & & & & & & \\
\hline
\end{tabular}




\section{ANEXO III}

\section{INSTRUÇÕES PARA COLETA DE DADOS}

\section{$\underline{\text { Relacionados a estrutura: }}$}

- Tempo programado da viatura para supervisão: tempo programado pela Secretaria Municipal de Saúde para cada Unidade Distrital.

- Hora disponível: hora de chegada da viatura à unidade de saúde.

- Hora de início: hora de saída da viatura da unidade de saúde.

- Hora de término: hora de chegada da viatura à unidade de saúde.

\section{$\underline{\text { Relacionados ao processo }}$}

- Supervisões

Supervisões realizadas: número de supervisões que o profissional de saúde realizou no dia.

Supervisões observando a tomada da medicação: quando o paciente toma a medicação na presença do profissional de saúde durante a supervisão domiciliar.

- Ocorrências:

Relacionadas ao serviço: problemas ou dificuldades que estão relacionadas à infra-estrutura, recursos humanos, suprimento de medicação etc., enfrentadas pelo profissional de saúde durante a supervisão.

Relacionadas ao paciente/família: problemas ou dificuldades que não correspondem ao serviço, que estão diretamente ligados à condição sócio-econômica e cultural (dentre outras) do paciente. 


\section{ANEXO IV \\ CONSENTIMENTO LIVRE E ESCLARECIDO}

Nome do trabalho: O Tratamento Supervisionado no Domicílio para o Controle da Tuberculose no Município de Ribeirão Preto, SP-Brasil: avaliação do desempenho.

Responsável: Roxana Isabel Cardozo Gonzales

\section{Informações sobre a pesquisa:}

Estamos realizando um estudo sobre o Tratamento Supervisionado (TS) no Programa de Controle de Tuberculose (PCT). Pretende-se conhecer de uma forma mais aprofundada aspectos relacionados à organização e funcionamento do TS, nesse sentido, solicitamos a sua colaboração respondendo alguma questões sobre este assunto. O estudo tem por finalidade conhecer e analisar as atividades de supervisão realizadas pelo profissional de saúde no domicílio do paciente. A sua participação é importante, pois, você estará contribuindo para que possamos conhecer e divulgar as nuanças do TS no PCT, assim como, a construção de elementos operacionais de fácil utilização no serviço para identificar problemas e possíveis soluções da prática do TS.

Em caso de desconforto ou prejuízo pessoal, no desenvolvimento do trabalho, você pode abandonar o estudo no momento que considere apropriado.

Se você compreendeu no que consiste o estudo e aceita participar, por favor, responda as seguintes perguntas e assine abaixo.

- Foi explicado a você, suficientemente, em que consiste este estudo?

$$
\text { Sim ( ) Não ( ) }
$$

Sua participação nesse estudo é voluntária?

\section{Sim ( ) Não ( )}

Assinatura:

Data: 
$\mathrm{Eu}_{2}$

portador de RG:

abaixo relacionados, concordo em participar.

1. A garantia de receber todos os esclarecimentos sobre as perguntas do questionário antes e durante o transcurso da pesquisa, podendo afastar-me em qualquer momento de assim o desejar, bem como está assegurado o absoluto sigilo das informações obtidas.

2. A segurança plena de que não serei identificado mantendo o caráter oficial da informação, assim como, está assegurada que a pesquisa não acarretará nenhum prejuízo individual ou coletivo.

3. A segurança de que não terei nenhum tipo de despesa material ou financeira durante o desenvolvimento da pesquisa, bem como, esta pesquisa não causará nenhum tipo de risco, dano físico ou mesmo constrangimento moral e ético ao entrevistado.

4. A garantia de que toda e qualquer responsabilidade nas diferentes fases da pesquisa é dos pesquisadores, bem como, sendo assegurado divulgação dos resultados finais nos órgãos de divulgação científica em que a mesma seja aceita.

5. A garantia de que todo o material resultante será utilizado exclusivamente para a construção da pesquisa e ficará sob a guarda dos pesquisadores, podendo ser requisitado pelo entrevistado a todo momento.

Tenho ciência do exposto acima e desejo participar da pesquisa.

Ribeirão Preto, , de de

\section{Assinatura do entrevistado}

